\title{
5. NEOGENE PLANKTONIC FORAMINIFERS FROM DEEP SEA DRILLING PROJECT SITES 502 AND 503 1
}

\author{
L. D. Keigwin, Jr., ${ }^{2}$ Graduate School of Oceanography, University of Rhode Island, Kingston, Rhode Island
}

\begin{abstract}
Deep Sea Drilling Project Sites 502 (Colombian Basin, western Atlantic Ocean) and $\mathbf{5 0 3}$ (eastern equatorial Pacific Ocean) are well located for comparison of the late Neogene paleoceanographic history of the tropical Atlantic and $\mathrm{Pa}$ cific oceans. Comparing the faunal and floral history at each location should reveal changes arising from the late Neogene shoaling of the Isthmus of Panama and the separation of the tropical oceans.

At each site we recovered an apparently continuous, largely undisturbed sedimentary sequence from Holocene to about $8 \mathrm{~m} . y$. in age. Tropical and subtropical planktonic foraminifers occur throughout each sequence, although diversity is lower and preservation poorer in the Pacific. At each location the Miocene/Pliocene boundary is defined by the first appearance of Globorotalia tumida, the early-late Pliocene boundary is defined by the extinction of Sphaeroidinellopsis, and the Pliocene/Pleistocene boundary is defined by the first appearance of $G$. truncatulinoides.

Planktonic foraminiferal assemblages at Sites 502 and 503 are generally similar until the early Pliocene when the faunal histories diverge. Two important exceptions are the delayed first occurrence of Pulleniatina at the Atlantic site (4.4 Ma) relative to the Pacific site (5.5 Ma) and the common presence of sinistral Neogloboquadrina acostaensis and sinistral $N$. pachyderma at the Atlantic site. Sinistral N. acostaensis is rare at the Pacific site, and sinistral N. pachyderma is absent entirely. The significance of sinistral $N$. pachyderma at Site $\mathbf{5 0 2}$ is unclear. If this phenotype is due to cool water at this location, it might reflect seasonal upwelling because the fauna is otherwise tropical-subtropical.

As noted by other workers, the first planktonic foraminiferal evidence for increasing Atlantic-Pacific provinciality occurs in the early Pliocene at $4 \mathrm{Ma}$ with the appearance of Pulleniatina spectabilis in the Pacific and its exclusion from the Atlantic. Subsequent to that, Pulleniatina disappeared from the Atlantic $(3.3 \mathrm{Ma})$ and did not reappear until about 2.1 Ma, whereas it ranged continuously in the Pacific. The strongest biogeographic evidence based on planktonic foraminifers for the separation of the two tropical oceans by the Panama Isthmus has been the development of an endemic lineage of Globorotalia in the Atlantic. Members of this group become numerically important in the late Pliocene and give tropical Atlantic faunas of that age a distinctive appearance. Until recently the more advanced members of this lineage have not been recorded from Pacific sediments. At Site 503 the distinctive species $G$. pertenius first appears at 3.3 Ma and last appears at 3.2 Ma, whereas at the Atlantic site it extends to $2.5 \mathrm{Ma}$. The short range of this species in the Pacific and the complete absence of $G$. miocenica is further evidence that by about 3 Ma the emergent Panama Isthmus was an effective barrier to the exchange of tropical surface waters between the Atlantic and Pacific.
\end{abstract}

\section{INTRODUCTION}

Deep Sea Drilling Project (DSDP) Leg 68 was conceived to test the newly developed hydraulic piston corer (HPC) in Atlantic and Pacific sediments and, if successful, to provide high-resolution stratigraphies. Comparing stratigraphic results between the two oceans would be useful in studying the late Neogene paleoceanographic effects of the closing of the Panama Isthmus, the initiation of permanent Northern Hemisphere glaciation, and the possible relation between the two. Sites 502 and 503 were cored near previously drilled Sites 154 and 83 , respectively. Site 502 holes are located at $11^{\circ} 29.4^{\prime} \mathrm{N}$ and $79^{\circ} 22.7^{\prime} \mathrm{W}$ at about 3051 meters water depth, approximately $100 \mathrm{~km}$ east of Site 154 (Edgar, Saunders, et al., 1973). The 153-meter pelagic sequence at DSDP 154 lies on a volcanic ash turbidite, which forms a prominent reflector and was the major objective of drilling in the western Colombian Basin. The 7 to $8 \mathrm{~m} . y$. old sequence at Site 502 lies on an uplifted block and does not contain the turbidite found at Site 154.

${ }^{1}$ Prell, W. L., Gardner, J. V., et al., Init. Repts. DSDP, 68: Washington (U.S. Govt. Printing Office).

2 Present address: Department of Geology and Geophysics, Woods Hole Oceanographic Institution, Woods Hole, Massachusetts.
Site 503 holes are located at $4^{\circ} 04.04^{\prime} \mathrm{N}$ and $95^{\circ}$ $38.21^{\prime} \mathrm{W}$ at a water depth of 3672 meters. Nearby Site 83 (Hays et al., 1972) was only spot-cored in the late Miocene sequence and was thought to reach the middle Miocene, but the sediments were badly disturbed by the rotary drilling process (see Prell, Gardner, et al., 1980, fig. 2). At Site 503 the HPC recovered a largely undisturbed 234-meter sequence to within about 10 meters of basement. Based on microfossil ranges, the oldest sediment is estimated to date to $8 \mathrm{Ma}$, about the same as Site 502 (see Kent and Keigwin, this volume).

Sediment at Site 502 grades with increasing depth from a foraminiferal and nannofossil marl to a calcareous and ash-bearing clay. Planktonic foraminifers are generally common and well preserved, especially in samples above 110 to 115 meters sub-bottom. Planktonic foraminifers are generally less abundant and often show effects of calcium carbonate dissolution in the siliceous-bearing marls of Site 503 .

\section{METHODS AND RESULTS}

The preliminary biostratigraphy presented in this chapter is based largely on Miocene and Pliocene core-catcher samples. Although corecatcher samples are routinely examined on board ship by biostratigraphers, we took special care to examine slices of sediment as thick as $2 \mathrm{~cm}$ from across the top of the core catcher when it was full. This was found to reduce the possible effects of down-core contaminants as 
well as to provide large samples for analysis of biostratigraphy and stable isotopes (Keigwin, this volume).

Core-catcher samples were washed in fresh water over a $63 \mu \mathrm{m}$ screen and then dried on the screen; that fraction greater than $175 \mu \mathrm{m}$ was examined. Samples processed ashore were prepared following Keigwin (1976). Species abundances were estimated using the method of Poore (1978).

Ranges of taxa have been refined by analyzing one sample per core section near intervals of faunal change. Ages of first and last appearance have been determined from magnetostratigraphy (Kent and Spariosu, this volume) by interpolating between the ages and depths of magnetic reversals in each hole. Because of relatively coarse sampling, the ages of biostratigraphic datums (Table 3) are accurate to within only about $0.1 \mathrm{Ma}$. Microfossil ranges are useful in patching together a composite section from the intervals of highest recovery in each hole of each site. Results in Table 3 suggest that Hole 502C datums are about 5 meters shallower than those of the other holes at this site.

Useful zonations have been developed for the Caribbean by Bolli and Premoli-Silva (1973) and for the east equatorial Pacific by Jenkins and Orr (1972) and Kaneps (1973). The zonation of Jenkins and Orr (1972) is used in this study because it is applicable to both Atlantic and Pacific faunas. The Miocene/Pliocene boundary is based on the first appearance of Globorotalia tumida and the Pliocene/Pleistocene boundary (as used here) is based on the distinctive first appearance of G. truncatulinoides at each site. The last occurrence of Globigerinoides obliquus, which is also a useful marker for the Pliocene/ Pleistocene boundary (Saito et al., 1975; Haq et al., 1977; Thompson and Sciarillo, 1978), occurs near the first appearance of G. truncatulinoides (Tables 1 and 2). Although the Pliocene is not formally divided into time-rock units, it is informally divided here into upper and lower parts based on the last appearance of Sphaeroidinellopsis. This extinction is a useful marker for the appearance of cooler faunal elements in low-latitude sites (Parker, 1967; Keigwin, 1976) and stable isotopic and lithologic indications of permanent Northern Hemisphere ice-sheet accumulation (Berggren, 1972; Shackleton and Opdyke, 1977; Shor and Poore, 1978; Keigwin and Thunell, 1979; Keigwin, this vol.). This datum is close to the first appearance of $G$. fistulosus, used to mark the zone of that name in the Jenkins and Orr (1972) zonation (Tables 1-3).

\section{HISTORY OF FAUNAL CHANGE AT SITE 502}

The late Neogene planktonic foraminiferal fauna in the western Caribbean is generally tropical and subtropical in character, dominated by species of keeled globorotaliids, Globigerinoides, Orbulina, and Neogloboquadrina. At both Sites 502 and 503 the keeled globorotaliids are largely the Globorotalia menardii group (Tables 1 and 2), which consists of G. menardii, G. limbata, and $G$. praemiocenica. The lower part of the upper Miocene (prior to about $6 \mathrm{Ma}$ ) is marked by intervals of calcium carbonate dissolution. This is reflected in rare foraminifers in the bottom 20 meters of Hole $502 \mathrm{~A}$ and the top few meters of Hole 502C. The upper part of this dissolution interval contains the upper Miocene carbon isotope shift, which, at least in the Pacific, is associated with a dissolution interval (Keller, 1980; Dunn et al., 1981). The pre-"carbon-shift" interval (below about $200 \mathrm{~m}$; see discussion in Keigwin, this volume) has common Globigerinoides quadrilobatus and G. obliquus, despite the generally poorer preservation. This lower part of the upper Miocene has few to common Neogloboquadrina acostaensis, and these are dominantly sinistral with the exception of one sample (502A-65,CC). Remaining few-to-common foraminifers are: Sphaeroidinellopsis subdehiscens, G. pleisotumida, Orbulina, Globigerina nepenthes, and G. bulloides. Below 215 meters there are three occurrences of a rare spe- cies identified as cf Catapsydrax unicavus (Table 1; Plate 1, Figs. 1-3). The preservation of these individuals is similar to the rest of the fauna, with no indication of other Paleogene or lower Neogene contaminants.

About 200 meters, in the upper Miocene (about 5 to 6 $\mathrm{Ma})$, there is a greater abundance of keeled globorotaliids and more G. falconensis (Table 1). There are two more intervals where dextral $N$. acostaensis is dominant $(50$ and $52, \mathrm{CC})$. The preservation of $\mathrm{CaCO}_{3}$ is generally improved over lower sediments, despite the probable shoaling of the CCD due to the Messinian "salinity crisis" (Ryan et al., 1973; Thunell (1981) and references therein). Within this uppermost Miocene interval Globigerinoides bulloideus (Plate 2, Figs. 1-4) last appears at 183 meters (Core 52,CC; estimated age, 5.8 $\mathrm{Ma})$, with a possible occurrence a little higher in the section $(42, \mathrm{CC}$, Table 1$)$. This species has a distinct last appearance high in the upper Miocene in two Panama Basin cores and is probably stratigraphically useful (Keigwin, 1976). Thompson (in press) finds $G$. bulloideus with a Tortonian-Messinian range at DSDP Leg 67 sites (Middle America Trench). A related form (here identified as G. cf bulloideus, Plate 2, Figs. 10-12) occurs in the middle Pliocene at Site 502, but has not been identified in the Pacific. $G$. cf bulloideus is distinguished from $G$. bulloideus by its higher spire. It resembles Globigerina cariacoensis in the way that Globigerinoides bulloideus resembles Globigerina bulloides.

By 173 meters (about $5.7 \mathrm{Ma}$ ) the sinistral phenotype of $N$. pachyderma (Plate 10, Figs. 4-8) is a common faunal element (estimated abundance is $30 \%$ of the planktonic foraminiferal fauna), and the sinistral form of $N$. acostaensis is abundant. These two forms are obviously related, but $N$. pachyderma may not reflect waters as cold as the modern high-latitude sinistral counterpart, because the rest of the planktonic fauna is strictly tropical and subtropical. In addition, there is evidence that the sinistral phenotype has been progressively restricted to cooler waters in the late Neogene (Kennett and Vella, 1975). Nevertheless, rare occurrences of the sinistral phenotype have been reported in the late Quaternary of DSDP Site 147 (Venezuelan Basin, Cariaco Trench) by Rögl and Bolli (1973). These workers attribute such apparently cool-water specimens to upwelling associated with the Cariaco Trench. Similar upwelling remains a possibility at Site 502 .

N. humerosa (Plate 9, Figs. 9-11) first occurs at 166 meters (about $5.6 \mathrm{Ma}$ ) and quickly becomes a common member of the fauna (Table 1). About 2 meters below the Miocene/Pliocene boundary, typical Globorotalia margaritae (Plate 5, Figs. 10-12) first appear, as noted by Berggren (1977) in his study of Rio Grande Rise piston cores (South Atlantic). Associated with the typical form is a thickened variety which persists into the lower Pliocene (Table 1; Plate 6, Figs. 1-3).

The Pliocene is marked by great faunal turnover, resulting in a fauna of modern appearance by the end of the epoch. Significant biostratigraphic events before 4.6 $\mathrm{Ma}$ in the lower Pliocene are the last appearance of $\mathrm{Glo}$ bigerinoides seigliei (Plate 3, Figs. 4-6) and the first appearance of Sphaeroidinella dehiscens with a small sup- 
plementary aperture (forma immatura, Plate 11, Figs. 5-6). In the temperate South Atlantic, Berggren (1977) has found the last occurrence of $G$. seigliei in the uppermost Miocene. These last occurrences are followed by the first appearance of G. margaritae evoluta at 126 meters and the migrational first appearance of $\mathrm{Pul}$ leniatina primalis (sinistral) and Globorotalia crassaformis by $4.3 \mathrm{Ma}(123 \mathrm{~m}$, Table 3$)$. The last occurrences of $G$. nepenthes, $N$. acostaensis (sinistral), and $N$. pachyderma (sinistral) are between about 110 and 120 meters down-core ( 4.0 to $4.2 \mathrm{Ma}$ ). The nearly simultaneous disappearance of the two Neogloboquadrina species suggests that the $N$. pachyderma existed in a clinal relationship with $N$. acostaensis, as noted by others (Srinivasan and Kennett, 1976). It still does not explain, however, what environmental factor led to sinistral coiling. This interval $(110-120 \mathrm{~m})$ is probably time-equivalent to the base of the pelagic section at nearby Hole 154A, because the lowest pelagic sample examined contained $G$. nepenthes overlain by a few meters of $\operatorname{sinistral} N$. pachyderma (Keigwin, 1978).

By about 3.9 Ma, the percent $\mathrm{CaCO}_{3}$ in Site 502 sediments became uniformly high (Gardner, this volume) raising the possibility that both Sites 502 and 154 were uplifted together into less corrosive water and above the effects of turbidites at deeper Site 154. The timing of these events (close to $4 \mathrm{Ma}$ ) is close to independent evidence from stable isotopes for the beginning of restricted circulation between the Atlantic and Pacific oceans (Keigwin, this volume). At 112 meters P. primalis changes from dominantly sinistral to dextral coiling ( 3.6 to $3.7 \mathrm{Ma}$ ) and last appears at 91 meters, 7 meters above the extinction of $G$. margaritae (3.6 Ma). Between 90 and 95 meters, $S$. dehiscens (forma immatura) is replaced by mature specimens, just after the first occurrence of $G$. exilis.

Evidence from fauna and stable isotopes shows the middle of the Pliocene to be a time of climatic deterioration. Evidence from stable isotopes is inferred to reflect the growth of permanent Northern Hemisphere ice sheets beginning about 3.2 Ma (Shackleton and Opdyke, 1977). Possible faunal evidence for cooling climate in the Colombian Basin are the first migrational appearances of $G$. puncticulata, G. inflata, G. hirsuta, and G. cariacoensis, and the last appearances of Sphaeroidinellopsis, Globoquadrina altispira, and G. conglomerata. In the upper Pliocene $N$. pachyderma (dextral) becomes an important faunal element in samples where the Globorotalia menardii group is absent. However, there are also changes which might be interpreted as evidence for warming. In the middle of the Pliocene Globigerinoides ruber increases in abundance and $G$. cf. bulloideus and $G$. fistulosus first occur. In addition there is the consistent presence of Globorotalia multicamerata and the diversification of the $G$. exilis lineage into $G$. miocenica and the exotic $G$. pertenuis. This complicated turnover of fauna is difficult to explain in terms of climatic cooling alone. Parker (1973) suggests that some Pliocene changes in fauna may be related to an ecological factor other than temperature. One possibility is salinity, which probably increased in the Caribbean during the Pliocene
(Keigwin, this volume). Useful datums in the uppermost Pliocene are the first occurrence of $N$. dutertrei $(2.5 \mathrm{Ma})$ and the reappearance of Pulleniatina at about $2 \mathrm{Ma}$.

\section{HISTORY OF FAUNAL CHANGE AT SITE 503}

Site 503 samples are marked by fewer planktonic foraminifers and lower diversity than are those from Site 502. Nevertheless, the dominant taxa throughout the section are the same as at Site 502: the Globorotalia menardii group, the Globigerinoides quadrilobatus group, the G. obliquus-G. ruber group, the SphaeroidinellaSphaeroidinellopsis group, Neogloboquadrina, and Globoquadrina altispira.

As in the upper Miocene at Site 502, Globigerinoides bulloideus last appears and Neogloboquadrina humerosa first appears between the "carbon shift" (6 Ma; Keigwin, this volume) and the Miocene/Pliocene boundary. Differences between the Atlantic and Pacific sections, however, are more significant. Pulleniatina primalis appears (perhaps migrational, see Srinivasan and Kennett, in press) in the uppermost Miocene (5.5 Ma) compared to the lower Pliocene in the Caribbean, and $N$. acostaensis is dominantly dextral. Two intervals of sinistral coiling occur near the base of the section, just above the "carbon shift." The higher of these intervals is probably time-equivalent with that reported from equatorial Pacific piston core RC12-66 (Saito et al., 1975 ) which has been used to date paleomagnetically the "carbon shift" (Keigwin and Shackleton, 1980). Even more important is the complete absence of sinistral $N$. pachyderma from Site 503. Globoquadrina dehiscens is more abundant in Site 503 than Site 502 samples, and last appears in 33,CC, where Globorotalia tumida first appears marking the Miocene/Pliocene boundary.

Most of the lower Pliocene at the Pacific site is similar to that at the Caribbean site. Notable differences are the absence of sinistral $N$. pachyderma, sinistral $N$. acostaensis, and $G$. margaritae. A few specimens of the short-ranging Pulleniatina spectabilis (Plate 11, Fig. 1) were found in Sample 503B-23,CC, probably at about the same time $(4 \mathrm{Ma})$ as in other locations (Parker, 1967; Keigwin, 1976). This species is not found in the Atlantic. Globigerina nepenthes is not common enough at this location for its last appearance to be a useful datum. Toward the end of the lower Pliocene interval (69-80 m) Globoquadrina conglomerata (Plate 3, Figs. 7-9) has its last occurrence and Globorotalia crassaformis and Globigerinoides fistulosus have their first occurrence. Since Globoquadrina conglomerata occurs in the modern Pacific (Parker, 1967; Thompson and Sciarillo, 1978), its disappearance at about 3.3 Ma at Site 503 must result from ecological change-perhaps cooling surface waters. Likewise, the middle Pliocene first occurrence of Globorotalia crassaformis results from ecological factors, because it appears earlier in higher latitudes (Srinivasan and Kennett, in press). Between the lower part of Core 21 and 19,CC (Hole 503B), the dominance of $P$. primalis coiling changes from sinistral to dextral. It is difficult to locate this change precisely because planktonic foraminifers are rare and sometimes absent entirely, but it occurs at about 3.7 
Table 1. Ranges and abundances (core-catcher samples only) of selected planktonic foraminiferal species at DSDP 502.

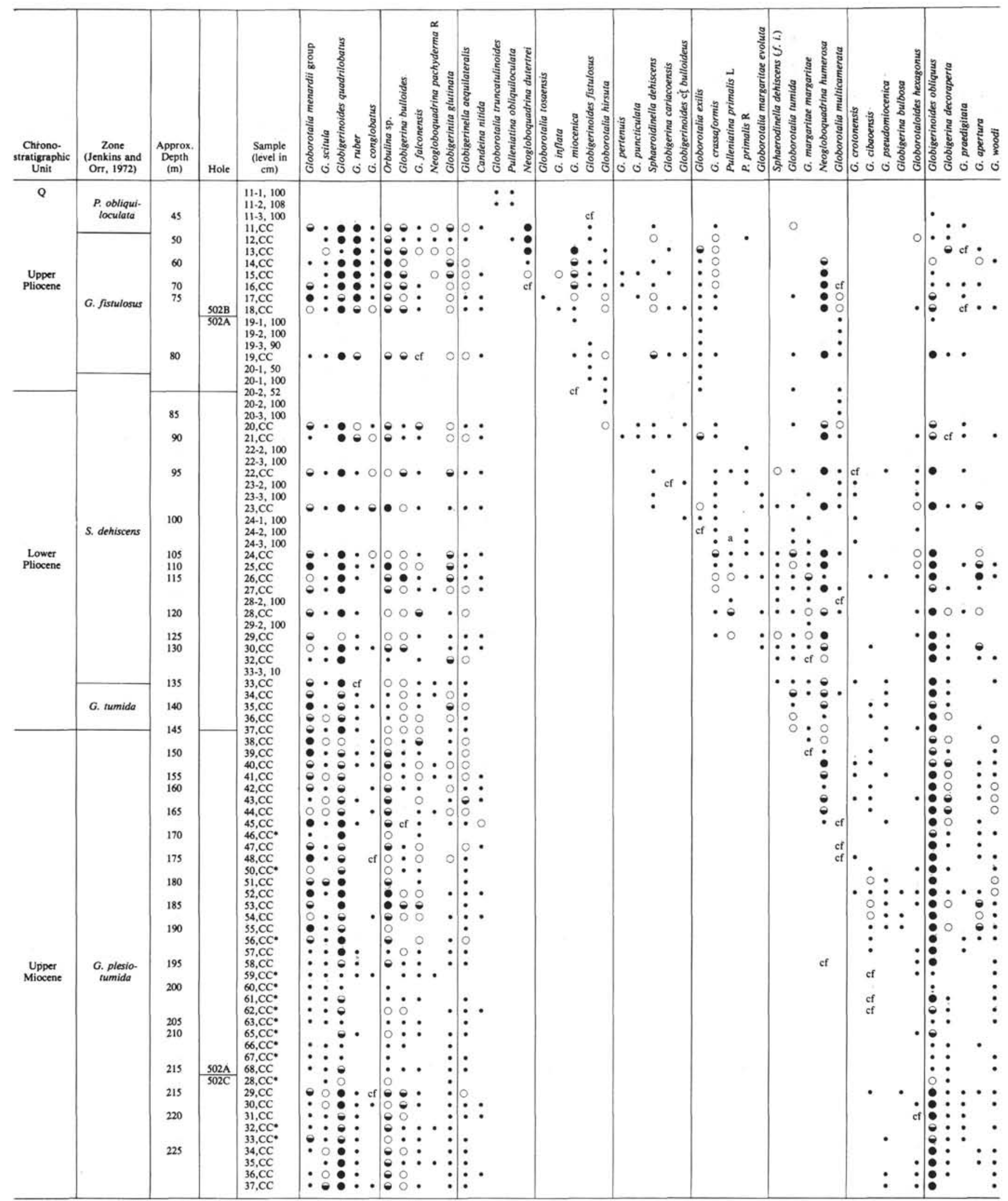

Note: Species abundance: $\mid \boldsymbol{\bullet}$ present, $O=$ few, $\boldsymbol{\emptyset}=$ common, $\bullet=$ abundant: $\boldsymbol{\bullet}=$ foraminifers rare.

Dominance change in $P$. primalis coiling shown by dotted line.
Last appearance at $502 \mathrm{~A}$, which differs slightly from $502 \mathrm{~B}$ (see Table 3 ). 
Table 1. (Continued).

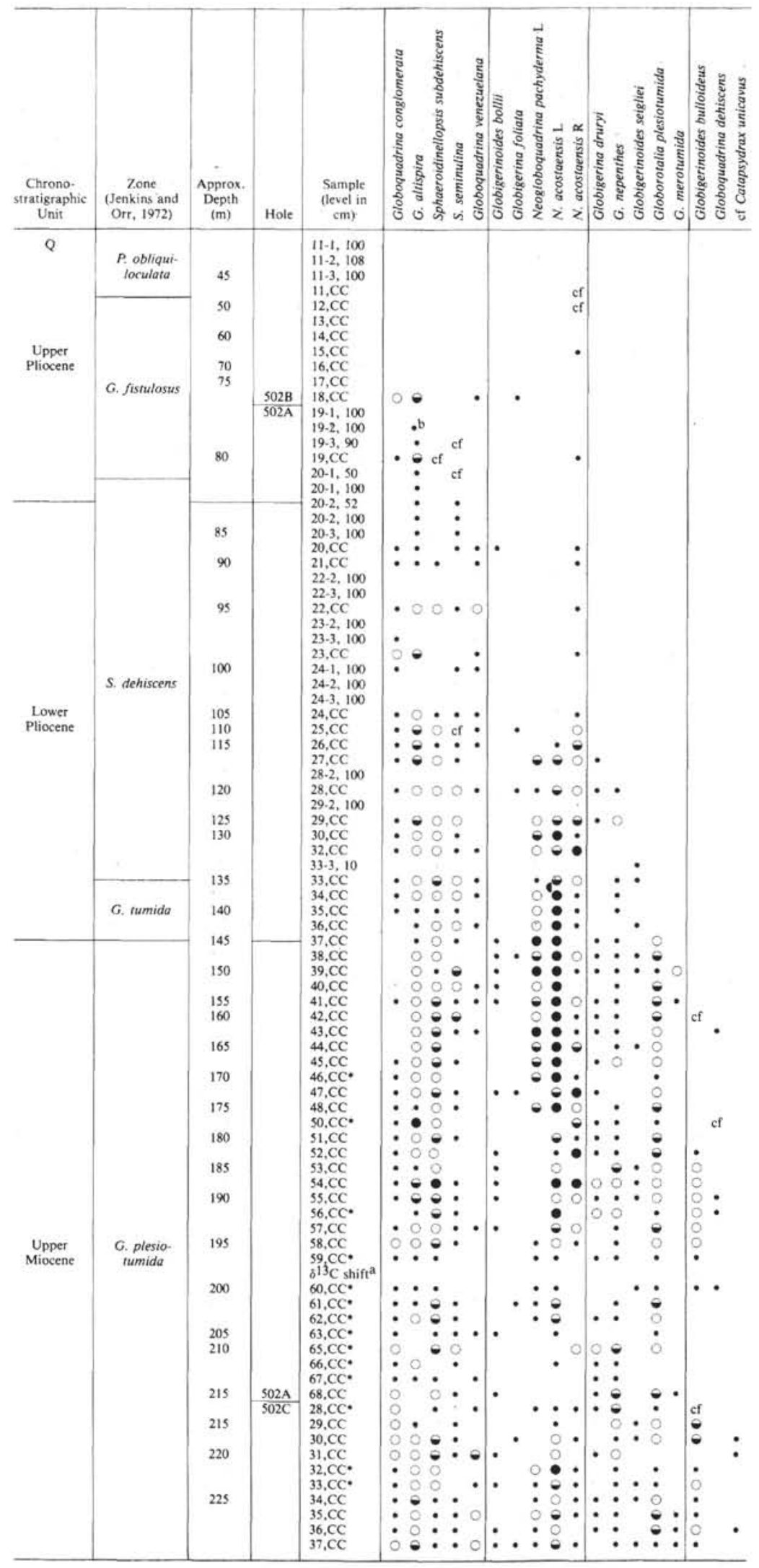


Table 2. Ranges and abundances (core-catcher samples only) of selected planktonic foraminiferal species at DSDP 503.

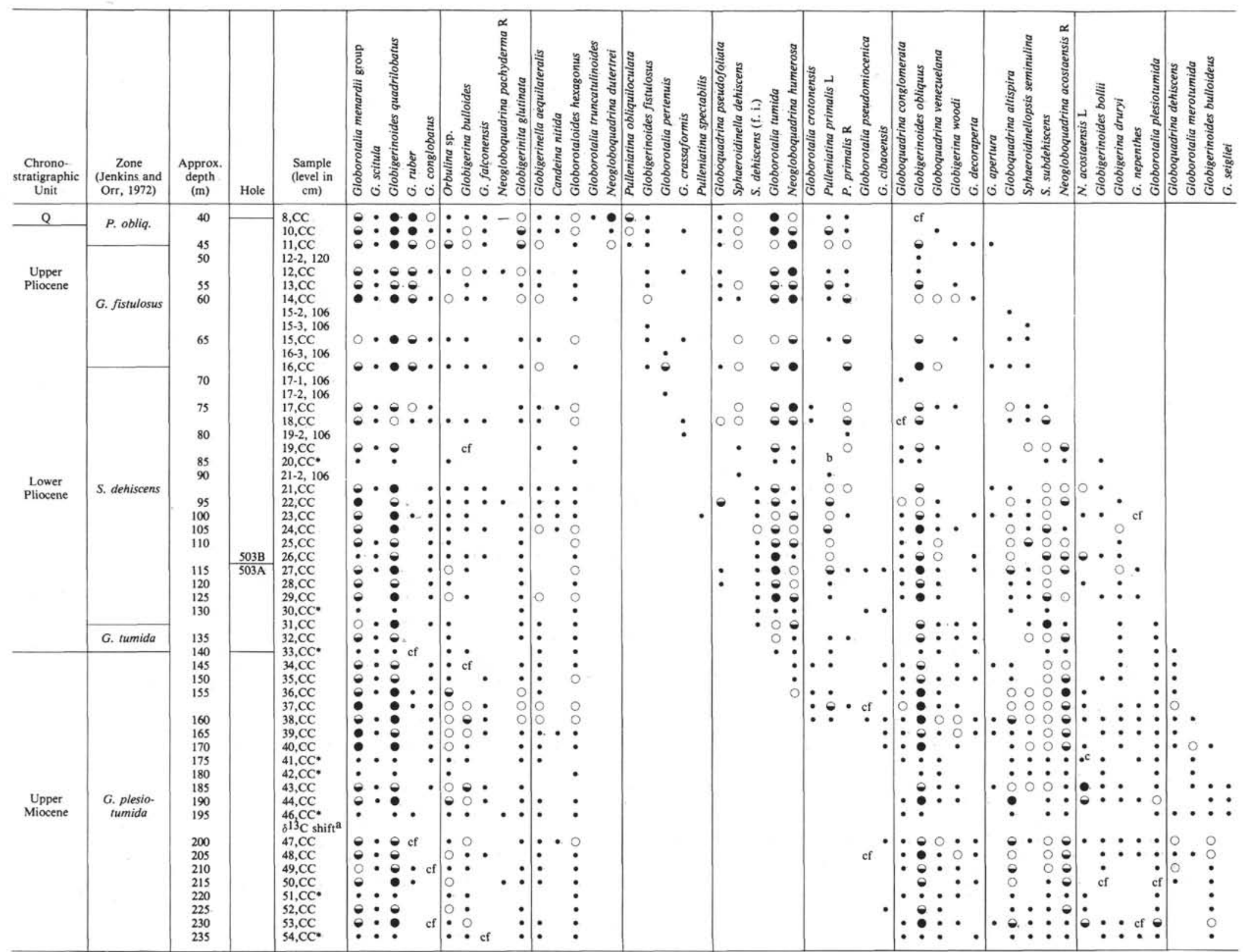


Table 3. Ages and depths of some DSDP Leg 68 planktonic foraminiferal datums.

\begin{tabular}{|c|c|c|c|c|c|c|c|c|c|c|c|c|c|c|c|c|c|c|c|}
\hline \multirow{2}{*}{\multicolumn{2}{|c|}{ Datum $^{a}$}} & \multicolumn{3}{|c|}{ Hole 502} & \multicolumn{3}{|c|}{ Hole $502 \mathrm{~A}$} & \multicolumn{3}{|c|}{ Hole $502 \mathrm{~B}$} & \multicolumn{3}{|c|}{ Hole $502 \mathrm{C}$} & \multicolumn{3}{|c|}{ Hole $503 \mathrm{~A}$} & \multicolumn{3}{|c|}{ Hole 503B } \\
\hline & & $\begin{array}{l}\text { Sample } \\
\text { (level in } \mathrm{cm} \text { ) }\end{array}$ & $\begin{array}{l}\text { Depth } \\
(\mathrm{m})\end{array}$ & $\begin{array}{l}\mathrm{Age}^{\mathrm{d}} \\
(\mathrm{Ma})\end{array}$ & $\begin{array}{c}\text { Sample } \\
\text { (level in } \mathrm{cm} \text { ) }\end{array}$ & $\begin{array}{c}\text { Depth } \\
\text { (m) }\end{array}$ & $\begin{array}{c}\mathrm{Age} \\
(\mathrm{Ma})\end{array}$ & $\begin{array}{l}\text { Sample } \\
\text { (level in } \mathrm{cm} \text { ) }\end{array}$ & $\underset{\text { Depth }}{\text { (m) }}$ & $\begin{array}{l}{ }^{A g e^{e}} \\
\text { (Ma) }\end{array}$ & $\begin{array}{c}\text { Sample } \\
\text { (evel in } \mathrm{cm} \text { ) }\end{array}$ & $\begin{array}{l}\text { Depth } \\
\text { (m) }\end{array}$ & $\begin{array}{l}\mathrm{Age}^{f} \\
(\mathrm{Ma})\end{array}$ & $\begin{array}{c}\text { Sample } \\
\text { (level in } \mathrm{cm} \text { ) }\end{array}$ & $\begin{array}{l}\text { Depth } \\
\text { (m) }\end{array}$ & $\begin{array}{l}\mathrm{Age} \\
(\mathrm{Ma})\end{array}$ & $\begin{array}{c}\text { Sample } \\
\text { (level in } \mathrm{cm} \text { ) }\end{array}$ & $\begin{array}{l}\text { Depth } \\
\text { (m) }\end{array}$ & $\begin{array}{l}\text { Age } \\
(\mathrm{Ma})\end{array}$ \\
\hline FA & G. truncartulinoides & $11, C C$ & 41.12 & 1.76 & $11 . \mathrm{CC}$ & 41.70 & 1.72 & $11-2,108$ & 43.92 & 1.77 & $1, \mathrm{CC}$ & 36.22 & 1.83 & $7, \mathrm{CC}$ & 27.68 & 1.40 & $8, \mathrm{CC}$ & 33.41 & 1.81 \\
\hline FA & P. obliquiloculata & $12, \mathrm{CC}$ & 44.40 & 1.88 & $14, \mathrm{CC}$ & 54.70 & 2.14 & $12, \mathrm{CC}$ & 48.92 & 2.06 & $3, \mathrm{CC}$ & 44.31 & 2.10 & $11, \mathrm{CC}$ & 45.46 & 2.35 & $11, \mathrm{CC}$ & 46.57 & 2.37 \\
\hline FA & N. dutertrei & - & - & - & - & - & - & $15, \mathrm{CC}$ & 60.46 & 2.50 & & - & - & $9-1,106$ & 33.61 & 1.60 & $11, \mathrm{CC}$ & 46.57 & 2.37 \\
\hline LA & G. altispira & $19-1,90$ & 76.10 & 2.95 & $19-2,100$ & 78.95 & 2.95 & $18 \cdot 1-75$ & 72.89 & 2.85 & $9 \cdot 2,70$ & 71.53 & 3.02 & $14, \mathrm{CC}$ & 57.67 & - & $15-2,106$ & 62.21 & 2.88 \\
\hline LA & Sphoeroidinellopsis & $20-1,100$ & 80.56 & 3.08 & $20-2,52$ & 83.50 & 3.08 & $19-2,75$ & 78.80 & 3.04 & $10-3,70$ & 75.29 & 3.22 & $15, \mathrm{CC}$ & 62.77 & - & $15-3,106$ & 63.71 & 2.91 \\
\hline FA & G. miocenica & $21, \mathrm{CC}$ & 87.28 & 3.50 & $19, \mathrm{CC}$ & 80.45 & 3.00 & $21, \mathrm{CC}$ & 89.45 & 3.31 & $10-1,60^{(\mathrm{cf})}$ & 72.20 & 3.04 & - & - & - & - & - & $\overline{0}$ \\
\hline FA & G. fistulasus & $20, \mathrm{CC}$ & 78.75 & 3.02 & $20-1,100$ & 81.97 & 3.04 & $19-1,75$ & 77.30 & 3.01 & $10-1,60$ & 72.20 & 3.04 & $15-2,106$ & 61.56 & - & $16, \mathrm{CC}$ & 68.36 & 3.23 \\
\hline FA & G. hirsuta & $19 . \mathrm{CC}$ & 78.75 & 3.02 & $20, \mathrm{CC}$ & 85.46 & 3.15 & $20-2,75$ & 83.20 & 3.15 & $13-1,75$ & 85.55 & 3.41 & - & - & - & - & - & - \\
\hline FA & G. puncticulatab & $20, \mathrm{CC}$ & 83.53 & 3.24 & $21.0 \mathrm{C}$ & 89.56 & 3.31 & $20, \mathrm{CC}$ & 85.30 & 3.21 & - & - & - & - & - & - & - & - & - \\
\hline LA & G. pertenuis & $17, \mathrm{CC}$ & 69.40 & 2.75 & $16, \mathrm{CC}$ & 66.84 & 2.54 & $15, \mathrm{CC}$ & 60.46 & 2.50 & $7, \mathrm{CC}$ & 59.99 & 2.63 & - & - & - & $16-3,106$ & 68.30 & 3.22 \\
\hline FA & G. pertenuis & $21, \mathrm{CC}$ & 87.28 & 3.50 & $21, \mathrm{CC}$ & 89.56 & 3.31 & $21, \mathrm{CC}$ & 89.45 & 3.31 & $14, \mathrm{CC}$ & 93.67 & 3.64 & - & - & - & $17 \cdot 2,106$ & 71.27 & 3.34 \\
\hline FA & G. crassaformis ${ }^{b}$ & $27-2,40$ & 111.24 & 4.01 & $29, \mathrm{CC}$ & 122.83 & 4.29 & & - & - & $18-2,75(\mathrm{cf})$ & 108.98 & 4.06 & - & - & - & $19-2,106$ & 75.77 & 3.48 \\
\hline FA & G. exilis & $21-2, \infty 0$ & 86.08 & 3.42 & $21, \mathrm{CC}$ & 89.56 & 3.31 & $22-3,75(\mathrm{cr})$ & 92.17 & 3.38 & $15-1,75$ & 94.33 & 3.66 & - & - & - & - & - & - \\
\hline LA & P. primalis & $23-2,100$ & 93.91 & 3.53 & $22-2,100$ & 92.41 & 3.41 & $22-2,75$ & 90.47 & 3.33 & $13-3,70$ & 88.48 & 3.49 & - & - & - & - & - & - \\
\hline FA & S. dehiscens & - & - & - & $23, \mathrm{CC}$ & 98.78 & 3.59 & - & - & - & - & - & - & - & - & - & $21-2,106$ & 88.91 & 3.84 \\
\hline \multirow{2}{*}{\multicolumn{2}{|c|}{ P. primalis L to $\mathrm{R}$}} & $24-3,134$ to & 101.55 & 3.75 & $24, \mathrm{CC}$ to & 103.18 & 3.71 & - & - & - & $15-1,75$ to & 94.33 & 3.66 & $20-2,96$ to & 83.30 & - & $19, \mathrm{CC}$ to & 80.96 & 3.62 \\
\hline & & $24-2,100$ & 99.70 & 3.70 & $24-3,100$ & 102.72 & 3.70 & - & - & - & $15-2,75$ & 95.83 & 3.70 & $20-3,108$ & 84.90 & - & $21-2,106$ & 88.91 & 3.84 \\
\hline FA & P. spectabilis & - & - & - & - & - & - & - & - & - & - & - & - & $25, C^{(c t)}$ & 103.00 & - & $23, \mathrm{CC}$ & 96.15 & 4.04 \\
\hline LA & G. margaritae & $23-4,100$ & 96.91 & 3.62 & $23-3,100$ & 98.38 & 3.58 & - & - & - & $14, \mathrm{CC}$ & 93.67 & 3.64 & - & - & - & - & - & - \\
\hline LA & N. acostaensis & - & - & - & $26, \mathrm{CC}$ & 111.85 & 3.95 & - & - & - & - & - & - & - & - & - & - & - & - \\
\hline LA & N. pachyderma (L) & $27-2,40$ & 111.24 & 4.01 & $27, \mathrm{CC}$ & 116.12 & 4.06 & - & - & - & $17 . \mathrm{CC}$ & 106.50 & 3.99 & - & - & - & & - & \\
\hline LA & G. nepenthes & $28, \mathrm{CC}$ & 117.00 & 4.19 & $28, \mathrm{CC}$ & 119.34 & 4.17 & - & - & - & $18-2,75$ & 108.98 & 4.06 & $27, \mathrm{CC}$ & 112.65 & 4.50 & $23, \mathrm{CC}^{(\mathrm{en})}$ & 96.15 & 4.04 \\
\hline LA & G. seigliei & $32-3,10$ & 133.56 & 4.76 & $33-3,10$ & 134.27 & 4.68 & & & & $24-1,101$ & 130.76 & 4.69 & $43, \mathrm{CC}$ & 185.59 & - & - & - & - \\
\hline FA & S. dehiscens (f.i) & $30, \mathrm{CC}$ & 125.76 & 4.46 & $33, \mathrm{CC}$ & 134.40 & 4.68 & - & - & - & - & - & - & $31, \mathrm{CC}$ & 133.74 & 5.09 & - & - & - \\
\hline FA & G. tumida & $35, \mathrm{CC}$ & 146.58 & 5.26 & $37, \mathrm{CC}$ & 145.14 & 5.26 & - & - & - & $26, \mathrm{CC}$ & 140.34 & 5.26 & $33 . \mathrm{CC}$ & 139.27 & 5.24 & - & - & - \\
\hline FA & G. margaritae & $35-2,100$ & 146.20 & 5.25 & $38, \mathrm{CC}$ & 147.49 & 5.28 & - & - & - & $23, \mathrm{CC}$ & 129.54 & 4.66 & - & - & - & - & - & - \\
\hline FA & N. humerase & - & - & - & $45, \mathrm{CC}$ & 166.04 & 5.55 & - & - & - & & - & - & $36, \mathrm{CC}$ & 154.59 & 5.43 & - & - & - \\
\hline FA & P. primalise & $28, \mathrm{CC}$ & 117.00 & 4.19 & $29 . \mathrm{CC}$ & 122.83 & 4.29 & - & - & - & $20, \mathrm{CC}$ & 119.16 & 4.38 & $38, \mathrm{CC}$ & 160.20 & 5.49 & - & - & - \\
\hline LA & G. bulloideus & - & - & - & $52, \mathrm{CC}$ & 182.33 & 5.78 & - & - & - & - & - & - & $40, \mathrm{CC}$ & 169.90 & 5.60 & - & - & - \\
\hline
\end{tabular}

$\mathrm{Ma}$, in excellent agreement with the change at Site 502 (Table 3). This supports Saito's (1976) contention that this coiling change is an oceanwide isochronous marker.

The species G. pertenuis (Plate 7, Figs. 1-7) is present at Site 503 (Tables 2 and 3, 3.2 to 3.3 Ma), and my identification of this species has been confirmed by J. Lamb and J. Beard (J. Lamb, personal communication). This species is considered typically "Atlantic" (by Stainforth et al., 1975) and has only been recently reported by the Indo-Pacific. Thunell (1981) reports it from the uppermost lower Pliocene in DSDP 214 (Indian Ocean) and Thompson (in press) may have found the same species at DSDP Leg 67 sites (Middle America Trench). The $G$. pertenuis at Site 503 are more robust than those found in the Caribbean, perhaps indicating that more fragile members of the population have been removed by selective dissolution. The first appearance of this species (3.3 $\mathrm{Ma}$ ) is apparently synchronous between Sites $\mathbf{5 0 2}$ and 503, but its range is truncated in the Pacific. Other synchronous datums at this location are the first occurrence of Globigerinoides fistulosus, the last occurrence of Sphaeroidinellopsis, and the appearance of few-to-common $G$. ruber.

As at the Caribbean site, the upper Pliocene is marked by the last occurrence of Globoquadrina altispira just above that of Sphaeroidinellopsis and by the simultaneous first appearances ( $2.4 \mathrm{Ma}$ ) of $P$. obliquiloculata and $N$. dutertrei higher in the section. Site 503 differs from 502 in the presence of Pulleniatina and the absence of Globorotalia exilis and G. miocenica through most of the upper Pliocene.

\section{BIOGEOGRAPHIC EVIDENCE FOR ISTHMUS CLOSING}

Vertebrate paleontologists studying South American land sections knew in the last century that for much of its Cenozoic history South America was isolated from North America. The development of the Central American land bridge and its effect on fossil mammals has recently been reviewed by Simpson (1980). Recent dating of volcanic ashes associated with South American fossil beds shows the first effects of intercontinental migration at about 7 or $8 \mathrm{Ma}$ (in the late Miocene), with increased interchange between 5 and $2 \mathrm{Ma}$, and an open land connection since the beginning of the Pleistocene (Marshall et al., 1977, 1979).

As terrestrial faunas of North and South America have become more similar, marine faunas of the Atlantic and Pacific have become more dissimilar. Woodring (1966) and Herm (1969) have shown increased provinciality of Atlantic and Pacific molluscs in Pliocene and Pleistocene times. Crough and Poag (1979) have reported the sporadic occurrence of the benthic foraminifer Amphistegina gibbosa in the California borderlands as recently as $1.8 \mathrm{Ma}$. This species is a shallow-reef dweller and is believed to have migrated from the Caribbean during warmings. Perhaps the sea level rose enough during these warmings to flood the newly emergent land bridge and permit migration of this species.

The effect of the closing Panama Isthmus on planktonic foraminifers has been discussed at length by Kaneps (1970) and Parker (1973). Both agree that by 3 to $4 \mathrm{Ma}$ there was faunal evidence for increasing provinciality. In particular Kaneps (1970) cited the evolution of the Globorotalia exilis-G. miocenica-G. pertenuis group and its apparent restriction to the Atlantic. Parker (1973) noted the absence of Pulleniatina spectabilis from the Atlantic, and the Atlantic late Pliocene and Pleistocene disappearance of Globoquadrina venezuelana and Globorotaloides hexagona. Saito (1976) and Keigwin (1978) called attention to the significance of Pulleniatina coiling and the temporary disappearance of 
this genus from the Atlantic. Increasing provinciality has continued into the late Pleistocene, affecting the ranges of Globorotalia tosaensis, Globoquadrina pseudofoliata, and pink-colored Globigerinoides ruber (Thompson et al., 1979).

Interesting comparisons can be made between the planktonic foraminiferal assemblages of Sites 502 and 503. The upper 120 meters of the Site 502 (Colombian Basin) section is similar to the pelagic sequence at nearby Site 154. As noted earlier, in the Site 154 range chart of Bolli and Premoli-Silva (1973) and by Keigwin (1978), $P$. primalis ranges for about $0.2 \mathrm{~m} . \mathrm{y}$. after the early Pliocene shift from sinistral to dextral coiling. Thus, following Saito's (1976) argument, this point marks sufficient uplift of the Panama Isthmus to restrict migration of Pulleniatina. The short interval of sinistral $N$. pachyderma reported in the bottom of the pelagic sequence at Site 154 (Keigwin, 1978) is actually the end of a long-ranging assemblage (about $1.5 \mathrm{~m} . \mathrm{y}$.) at Site 502 which became numerically important about $5.5 \mathrm{Ma}$. This assemblage is not present in Pacific Site 503, although it ranges through a short interval in the early Pliocene of Panama Basin Site 157 .(Keigwin, 1976). Curiously, related $N$. acostaensis is mostly sinistral throughout Sites 502 and dextral in Site 503. Another important difference between the sites in the late Miocene and early Pliocene is the delayed first appearance (by about 2 m.y.) of Pulleniatina in the Caribbean.

The most significant result of the biogeographic comparison of Sites 502 and 503 is the discovery of Globorotalia pertenuis in the Pacific. Its range is truncated in the Pacific sites at approximately 3.2 Ma, whereas in the Atlantic it lived until about $2.5 \mathrm{Ma}$ (Table 3). As with the last early Pliocene appearance of Pulleniatina in the Caribbean, the emergent isthmus probably stopped the exchange of genetic information between the two oceans, isolating the less well-adapted population. If after its evolution, $G$. pertenuis migrated from the Atlantic to the Pacific then it would be expected that earlier appearing $G$. exilis would have, too. Although I have not seen $G$. exilis (sensu stricto) in Pacific Sites 83, $84,157,158$, or 503 , I have found a related form ( $G$. limbata-G. exilis; Plate 5, Figs. 4-6) in the upper Miocene of Site 503. Jenkins and Orr (1972) report G. exilis from several DSDP Leg 9 sites, but their figured specimens differ significantly from those I have identified at Site 502 (Plate 4, Figs. 9-12). Recently, P. R. Thompson (in press) has identified $G$. cf exilis (perhaps equivalent to G. limbata-G. exilis at Site 503) from late Miocene eastern equatorial Pacific DSDP Sites 497 and 498. He also reports a "typical" middle Pliocene first appearance, with a last appearance at the same level as Sphaeroidinellopsis (3.1 Ma). This Pacific last appearance is distinctly earlier than that in Site 502 (Table 1) and close to the "truncated" Pacific last appearance of G. pertenuis. Thus, these two "Atlantic-type" Globorotalia have shorter ranges in the Pacific than the Atlantic, adding further evidence that the emergent Panama Isthmus was an effective barrier to the migration of planktonic organisms by 3.0 to $3.2 \mathrm{Ma}$.
At first there appears to be a contradiction between land-mammal evidence, which suggests that the North American-South American exchange began in the late Miocene and increased in the early Pliocene, and that from planktonic foraminifers, which show that AtlanticPacific provinciality began about $4 \mathrm{Ma}$. In fact the two lines of evidence are easily reconciled. As Simpson (1980) has pointed out, the first exchange of vertebrates was by waif dispersal, or "island hopping," which does not preclude the exchange of planktonic organisms through relatively deep channels between the inferred islands. By about $3 \mathrm{Ma}$, populations of planktonic foraminifers from the tropical Atlantic-Pacific were completely isolated and the exchange of terrestrial vertebrates accelerated, suggesting that the land bridge between the Americas was largely completed by this time.

\section{CONCLUSIONS}

Sites 502 and 503 contain complete successions of late Neogene and Quaternary (Holocene to about $8 \mathrm{Ma}$ ) tropical and subtropical planktonic foraminifers. Faunal diversity is higher in the Caribbean site, and preservation has improved there since $6 \mathrm{Ma}$. Significant differences include:

1) An enigmatic and numerically important population of sinistral Neogloboquadrina pachyderma between about 5.5 and $4 \mathrm{Ma}$ in the Caribbean. This species is always associated with warm-water faunal elements, suggesting that its presence does not indicate cold waters. It may, however, indicate seasonal upwelling.

2) The evolution of Pulleniatina primalis at about 5.5 $\mathrm{Ma}$ in the Pacific, but its exclusion from the Atlantic until approximately $4.2 \mathrm{Ma}$.

3) The gradual Pliocene divergence of Atlantic-Pacific faunal histories arising from completion of the Panama land bridge. This divergence is seen in the exclusion of $P$. spectabilis from the Atlantic, the temporary disappearance of $P$. primalis from the Atlantic at about 3.3 $\mathrm{Ma}$, and the absence of the Globorotalia exilis-pertenuis-miocenica lineage from the Pacific since 3.0 Ma.

\section{ACKNOWLEDGMENTS}

This study, reviewed by P. R. Thompson and R. C. Thunell, profited from the comments and suggestions of J. H. Beard, W. A. Berggren, B. H. Corliss, J. V. Gardner, J. P. Kennett, J. J. Lamb, T. S. Loutit, M. S. Srinivasan, P. R. Thompson, and R. C. Thunell. I thank D. Scales for operating the scanning electron microscope, D. Allison for typing the manuscript, and DSDP for inviting me to participate on Leg 68. I thank J. P. Kennett for supporting me as a Research Associate in the CENOP program. CENOP was funded through National Science Foundation Grant OCE79-14594. Woods Hole Oceanographic Institution Contribution No. 4859.

\section{REFERENCES}

Berggren, W. A., 1972. Late Pliocene-Pleistocene glaciation. In Laughton, A. S., Berggren, W. A., et al., Init. Repts. DSDP, 12: Washington (U.S. Govt. Printing Office), 953-964. , 1977. Late Neogene planktonic foraminiferal biostratigraphy of the Rio Grande Rise (South Atlantic). Mar. Micropaleo., 2:265-313.

Bolli, H. M., and Premoli-Silva, I., 1973. Oligocene to Recent planktonic foraminifera and stratigraphy of the Leg 15 sites in the Caribbean Sea. In Edgar, N. T., Saunders, J. B., et al., Init. Repts. DSDP, 15: Washington (U.S. Govt. Printing Office), 475-498. 
Crouch, R. W., and Poag, C. W., 1979. Amphistegina gibbosa d'Orbigny from the California borderlands: the Caribbean connection. J. Foram. Res., 9:85-105.

Dunn, D. A., Moore, T. C., Jr., and Keigwin, L. D., Jr., 1981. Atlantic-type carbonate stratigraphy in the Late Miocene Pacific. $\mathrm{Na}$ ture, 291:225-227.

Edgar, N. T., Saunders, J. B., et al., 1973. Init. Repts. DSDP, 15: Washington (U.S. Govt. Printing Office).

Hays, J. D., Cook, H. E., et al., 1972. Init. Repts. DSDP, 9: Washington (U.S. Govt. Printing Office).

Herm, D., 1969. Marine Pliozan and Pleistozan in Nord und MittelChile unser besonderer Berucksichtigung der Entwichlung der Mollusken-Faunen. Zitteliana, 2:1-159.

Jenkins, D. G., and Orr, W. N., 1972. Planktonic foraminiferal biostratigraphy of the eastern equatorial Pacific-DSDP Leg 9. In Hays, J. D., Init. Repts. DSDP, 9: Washington (U.S. Govt. Printing Office), 1059-1193.

Kaneps, A. G., 1970. Late Neogene biostratigraphy (planktonic foraminifera), biogeography, and depositional history [Ph.D. dissert.]. Columbia University, New York.

1973. Cenozoic planktonic foraminifera from the eastern equatorial Pacific Ocean. In van Andel, Tj. H., Heath, G. R., et al., Init. Repts. DSDP, 16: Washington (U.S. Govt. Printing Office), 713-745.

Keigwin, L. D., Jr., 1976. Late Cenozoic planktonic foraminiferal biostratigraphy and paleoceanography of the Panama Basin. Micropaleontology, 22:419-442.

1978. Pliocene closing of the Isthmus of Panama, based on biostratigraphic evidence from nearby Pacific Ocean and Caribbean Sea cores. Geology, 6:630-634.

Keigwin, L. D., Jr., and Shackleton, N. J., 1980. Uppermost Miocene carbon isotope stratigraphy of a piston core in the equatorial $\mathrm{Pa}$ cific. Nature, 284:613-614.

Keigwin, L. D., Jr., and Thunell, R. C., 1979. Middle Pliocene climatic change in the western Mediterranean from faunal and oxygen isotopic trends. Nature, 282:294-296.

Keller, G., 1980. Middle to late Miocene planktonic foraminiferal datum levels and paleoceanography of the north and southeastern Pacific Ocean. Mar. Micropaleo., 5:249-281.

Kennett, J. P., and Vella, P., 1975. Late Cenozoic planktonic foraminifera and paleoceanography at DSDP Site 284 in the cool subtropical South Pacific. In Kennett, J. P., Houtz, R. E., et al., Init. Repts. DSDP, 29: Washington (U.S. Govt. Printing Office), 769-799.

Marshall, L. G., Butler, R. F., Drake, R. E., Curtis, G. H., and Tedford, R. H., 1979. Calibration of the great American interchange. Science, 204:272-279.

Marshall, L. G., Pascual, R., Curtis, G. H., and Drake, R. E., 1977. South American geochronology: Radiometric time scale for middle to late Tertiary mammal-bearing horizons in Patagonia. Science, 195:1325-1328.

Parker, F. L., 1967. Late Tertiary biostratigraphy (planktonic foraminifera) of tropical Indo-Pacific deep-sea cores. Bull. Am. Paleontol., 52:115-208.

1973. Late Cenozoic biostratigraphy (planktonic foraminifera) of tropical Atlantic deep-sea sections. Rev. Esp. Micropaleo., 5:253-289.

Poore, R. Z., 1978. Oligocene through Quaternary planktonic foraminiferal biostratigraphy of the North Atlantic: DSDP Leg 49. In
Luyendyk, B. P., Cann, J. R., et al., Init, Repts. DSDP, 49: Washington (U.S. Govt. Printing Office), 447-517.

Prell, W. L., Gardner, J. V., et al., 1980. Hydraulic piston coring of late Neogene and Quaternary sections in the Caribbean and equatorial Pacific: Preliminary results of Deep Sea Drilling Project Leg 78. Bull. Geol. Soc. Am. (Pt. I), 91:433-444.

Rögl, F., and Bolli, H. M., 1973. Holocene to Pleistocene planktonic foraminifera of Leg 15, Site 147 (Cariaco Basin [Trench], Caribbean Sea) and their climatic interpretation. In Edgar, N. T., Saunders, J. B., et al., Init. Repts. DSDP, 15: Washington (U.S. Govt. Printing Office), 553-616.

Ryan, W. B.F., Cita, M.B., Rawson, M. D., Burckle, L. H., and Saito, T., 1973. A paleomagnetic assignment of Neogene stage boundaries and the development of isochronous datum planes between the Mediterranean, the Pacific and Indian Oceans in order to investigate the response of the world ocean to the Mediterranean "salinity crisis." Riv. Ital. Pal. Strat., 80: 631-688.

Saito, T., 1976. Geological significance of coiling direction in the planktonic foraminifera Pulleniatina. Geology, 4:305-309.

Saito, T., Burckle, L. H., and Hays, J. D., 1975. Late Miocene to Pleistocene biostratigraphy of equatorial Pacific sediments. In Saito, T., and Burckle, L. H. (Eds.), Late Neogene Epoch Boundaries: New York (Micropaleontology Press), pp. 226-244.

Shackleton, N. J., and Opdyke, N. D., 1977. Oxygen isotope and paleomagnetic evidence for early Northern Hemisphere glaciation. Nature, 270:216-219.

Shor, A. N., and Poore, R. Z., 1978. Bottom currents and ice rafting in the North Atlantic: Interpretation of Neogene depositional environments of Leg 49 cores. In Luyendyk, B. P., Cann, J. R., et al., Init. Repts. DSDP, 49: Washington (U.S. Govt. Printing Office), 859-872.

Simpson, G. G., 1980. Splendid Isolation: New Haven (Yale University Press).

Srinivasan, M. S., and Kennett, J. P., 1976. Evolution and phenotypic variation in the Late Cenozoic Neogloboquadrina dutertrei plexus. In Takayanagi, Y., and Saito, T. (Eds.), Progress in Micropaleontology: New York (Micropaleontology Press), 329-355. , in press. A review of Neogene planktonic foraminiferal biostratigraphy: Applications in the equatorial and South Pacific. Soc. Econ. Paleontol. Mineral. Spec. Vol.

Stainforth, R. M., Lamb, J. J., Luterbacher, H., Beard, J. H., and Jeffords, R. M., 1975. Cenozoic planktonic foraminiferal zonation and characteristics of index forms: Lawrence, Kansas (University of Kansas Paleontological Institute).

Thompson, P. R., in press. Foraminifera of the Middle America Trench: DSDP Leg 67. In von Huene, R., Aubuoin, J., et al., Init. Repts. DSDP, 67: Washington (U.S. Govt. Printing Office).

Thompson, P. R., Be, A.W.H., Duplessy, J.-C., and Shackleton, N. J., 1979. Disappearance of pink-pigmented Globigerinoides ruber at 120,000 yr BP in the Indian and Pacific Oceans. Nature, 280:554-558.

Thompson, P. R., and Sciarrillo, J. R., 1978. Planktonic foraminiferal biostratigraphy in the Equatorial Pacific. Nature, 275:29-33.

Thunell, R. C., 1981. Late Miocene-Early Pliocene planktonic foraminiferal biostratigraphy and paleoceanography of low latitude marine sequences. Marine Micropaleo.

Woodring, W. P., 1966. The Panama land bridge as a sea barrier. Am. Philo. Soc. Proc., 110:425-433. 


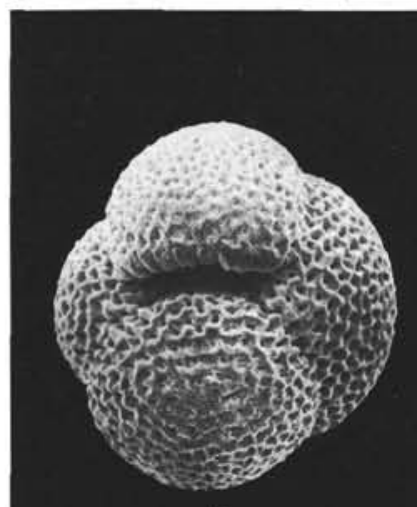

1

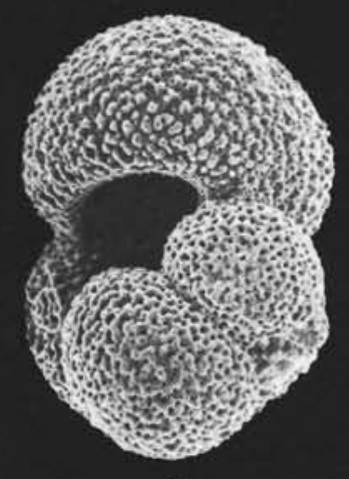

5

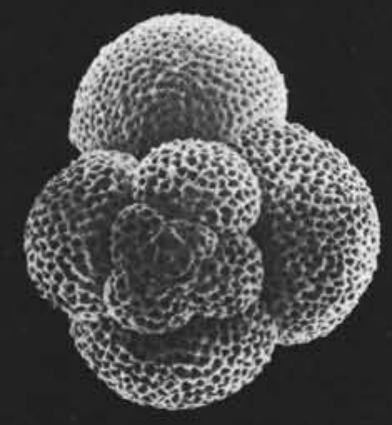

9

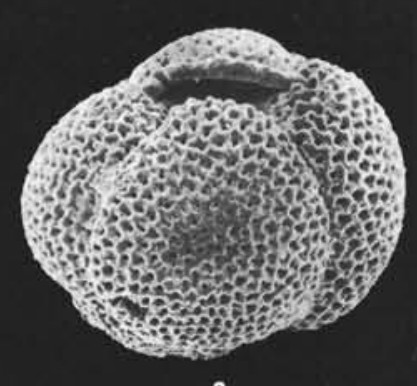

2

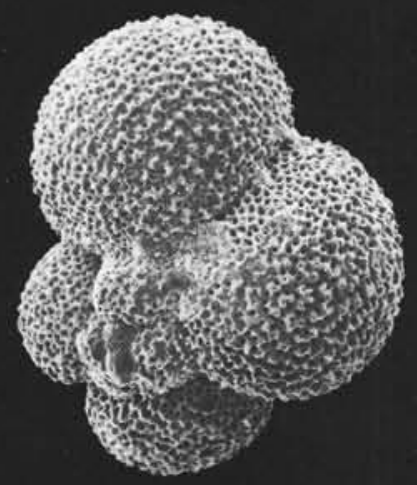

6

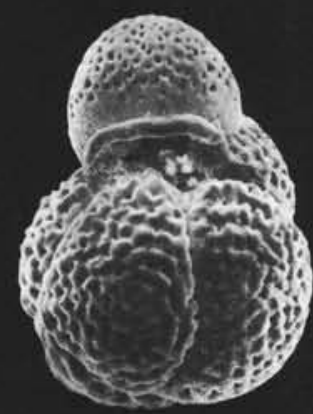

10

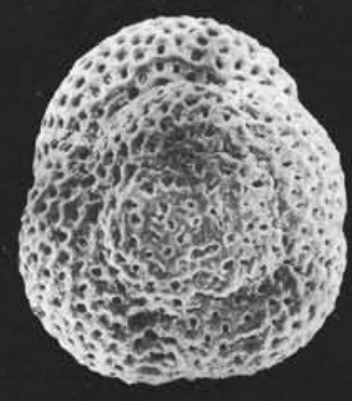

3

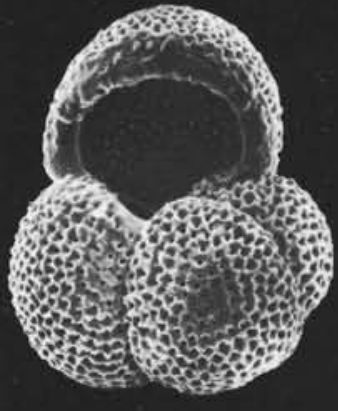

7

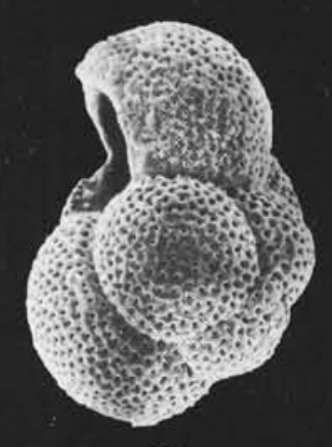

8

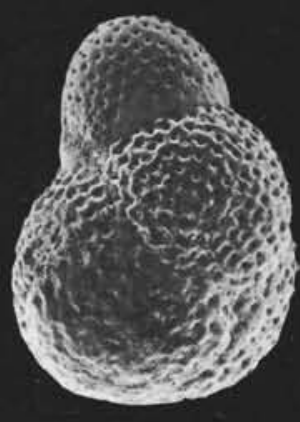

12

Plate 1. Neogene planktonic foraminifers. 1-3. cf Catapsydrax unicavus, Sample 502C-30,CC, upper Miocene, (1) ventral view $\times 110$, (2) side view $\times 115$, (3) dorsal view $\times 161$, 4-6. Globigerina bulloides, Sample 502C-29,CC, upper Miocene, (4) ventral view $\times 125$, $(5)$ side view $\times 159$, (6) dorsal view $\times 143$. 7-9. Globigerina cariacoensis, Sample 502A-23-2, $100 \mathrm{~cm}$., lower Pliocene, (7) ventral view $\times 120,(8)$ side view $\times 113$, (9) dorsal view $\times 115$. 10-12. Globigerina nepenthes, lower Pliocene, (10) Sample 502A-29,CC, ventral view $\times 133$, (11) Sample 502A-29,CC, side view $\times 178$, (12) Sample 50A-37,CC, dorsal view $\times 127$. 


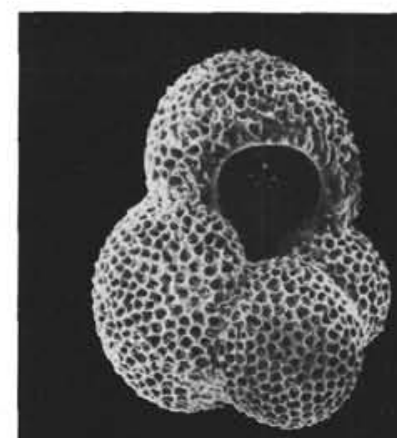

1

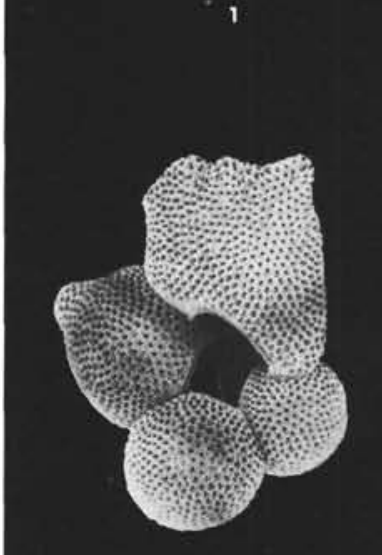

5

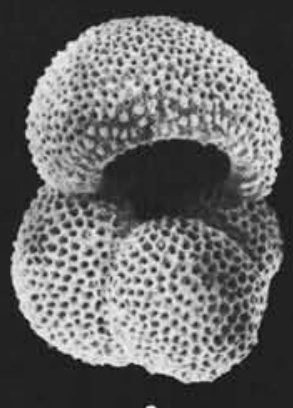

2
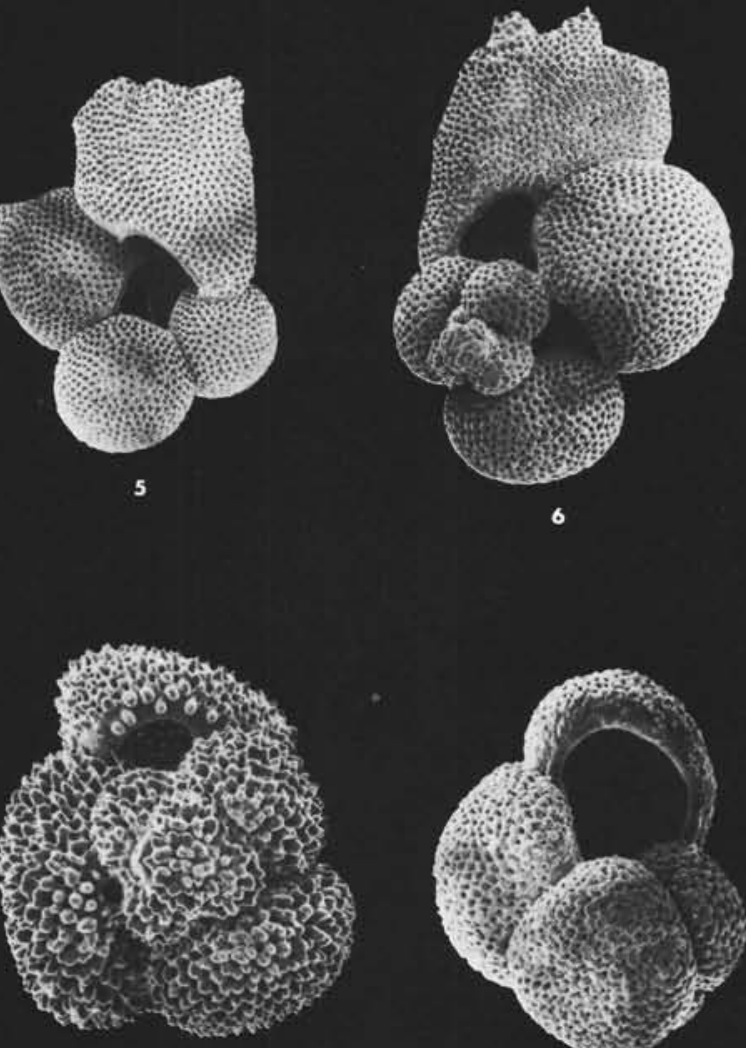

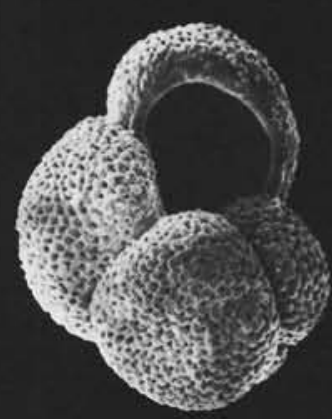

10

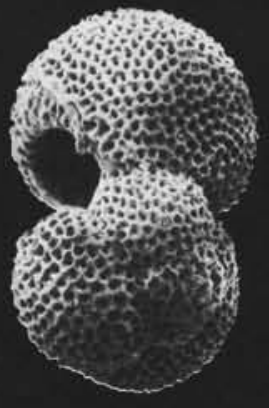

3

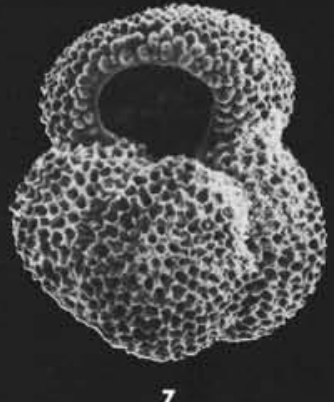

7

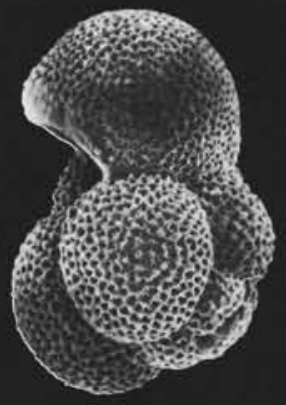

11

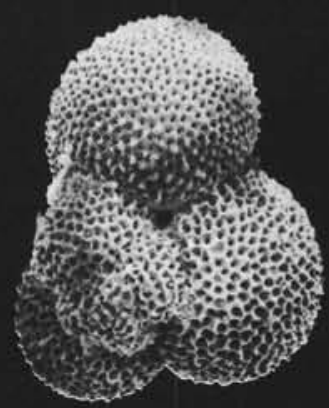

4

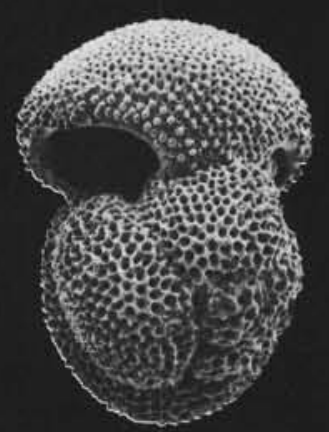

8

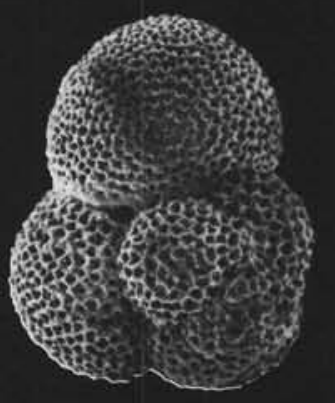

12

Plate 2. Neogene planktonic foraminifers. 1-4. Globigerinoides bulloideus, upper Miocene, (1) Sample 502C-32,CC, ventral view $\times 115$. $2-4$. Sample 503A-46,CC, (2) ventral view $\times 106$, (3) side view $\times 122$, (4) dorsal view $\times 122$. 5-6. Globigerinoides fistulosus, Sample 502A-20-1, 50 $\mathrm{cm}$, upper Pliocene, (5) ventral view $\times 53$, (6) dorsal view $\times 60$. 7-9. Globigerinoides obliquus, Sample 503A-39-1, 106 cm, upper Miocene, (7) ventral view $\times 115,(8)$ side view $\times 99$, (9) dorsal view $\times 115$. 10-12. Globigerinoides $\mathrm{cf}$ bulloideus, Sample 502A-23-2, $100 \mathrm{~cm}$, lower Pliocene, (10) ventral view $\times 110$, (11) side view $\times 106$, (12) dorsal view $\times 121$. 


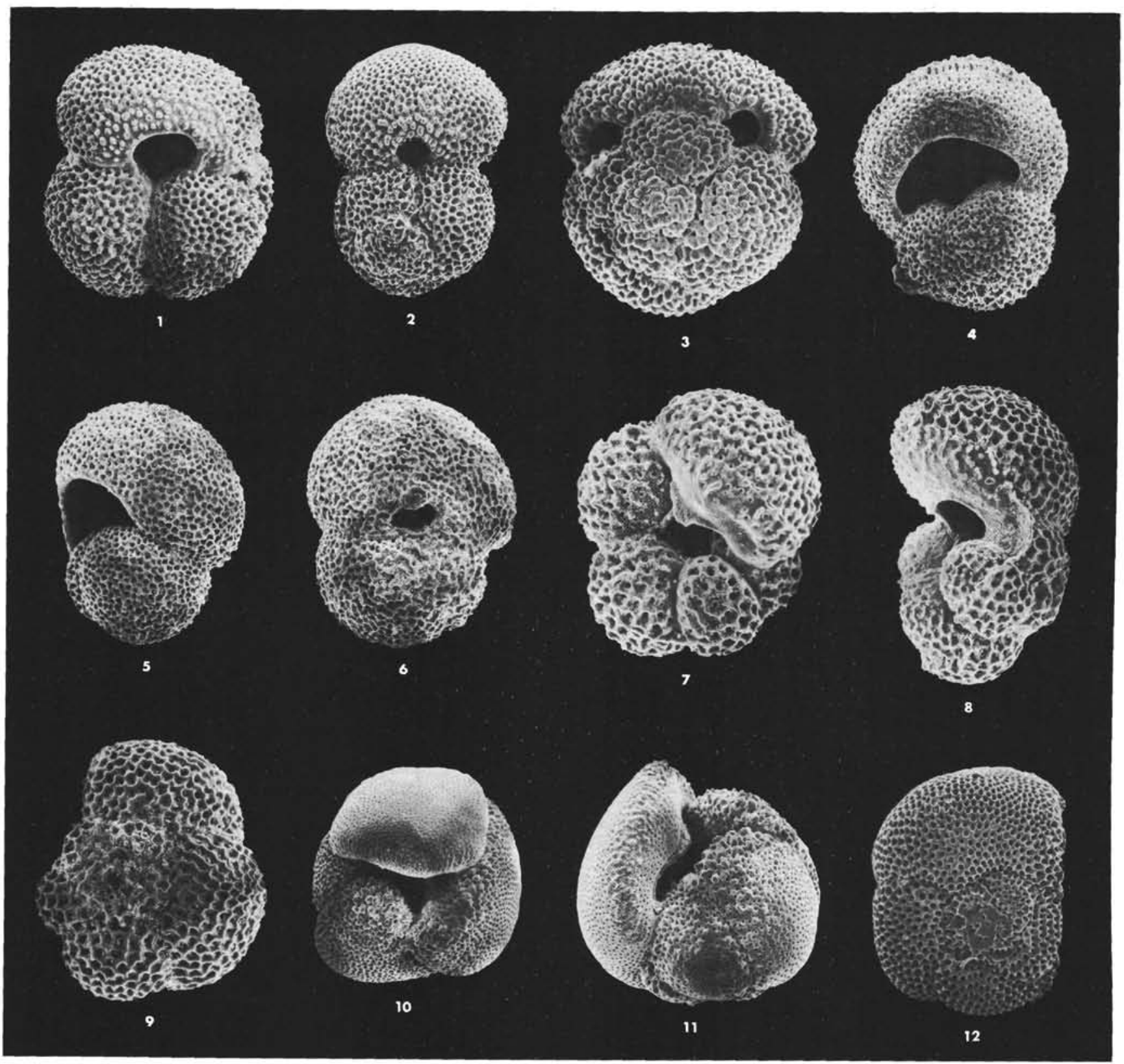

Plate 3. Neogene planktonic foraminifers. 1-3. Globigerinoides ruber, (1) Sample 502C-34,CC, upper Miocene, ventral view $\times 110$, (2) Sample 502C-33,CC, upper Miocene, side view $\times 126$, (3) Sample 503A-15-3, $74 \mathrm{~cm}$., upper Pliocene, dorsal view $\times 92$. 4-6. Globigerinoides seigliei, upper Miocene, (4) Sample 502C-28,CC, ventral view $\times 100$, (5) Sample 502C-30,CC, side view $\times 115$, (6) Sample 502C-28,CC, dorsal view $\times 100$. 7-9. Globoquadrina conglomerata, (7) Sample 502A-47,CC, upper Miocene, ventral view $\times 166$, (8) Sample 502A-24,CC, lower Pliocene, side view $\times 150$, (9) Sample 502A-24,CC, lower Pliocene, dorsal view $\times 156.10-12$. Globoquadrina dehiscens, upper Miocene, (10) Sample 503A-33,CC, ventral view $\times 88$, (11) Sample 503A-33,CC, side view $\times 94$, (12) Sample 503A-34,CC, dorsal view $\times 102$. 


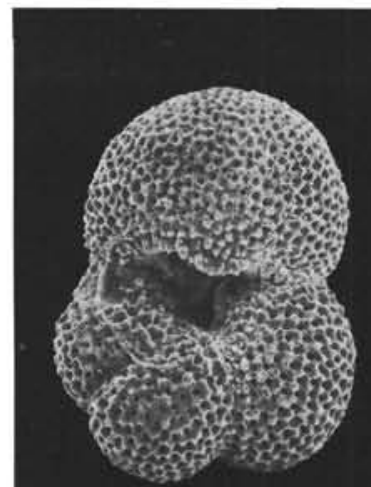

1

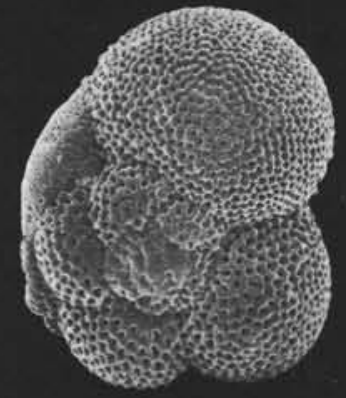

5

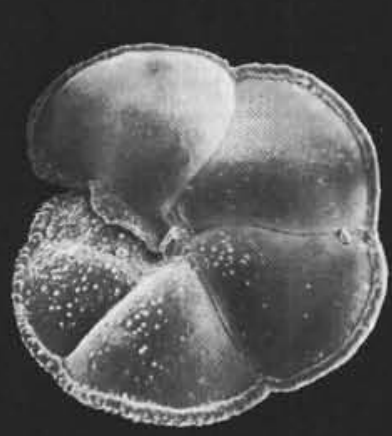

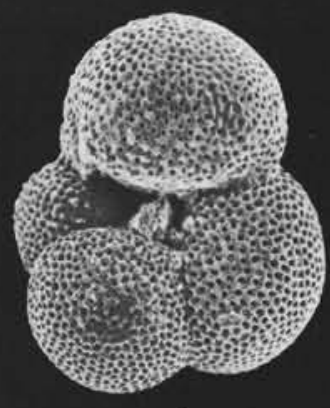

2
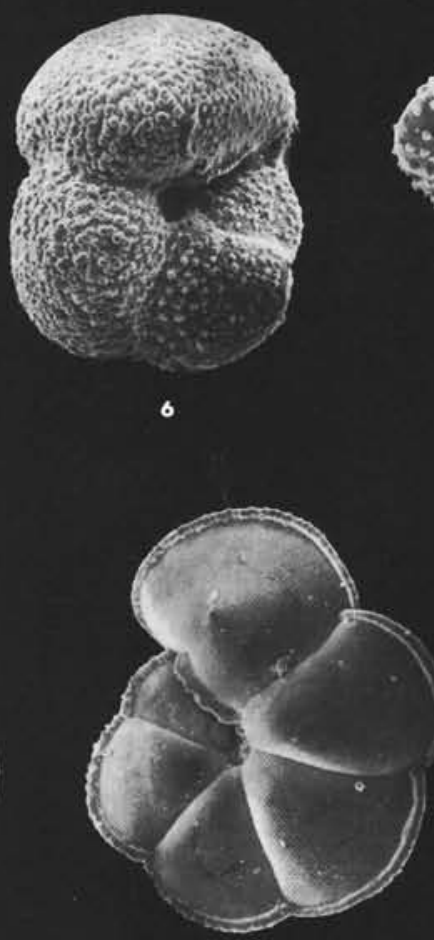

10

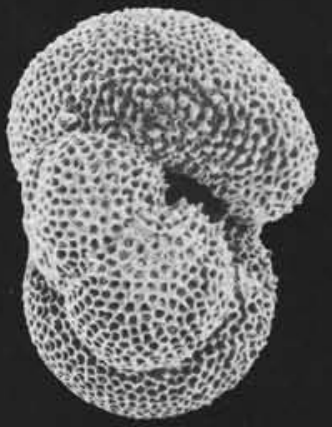

3

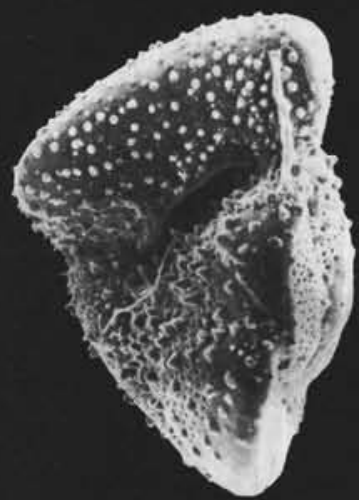

7
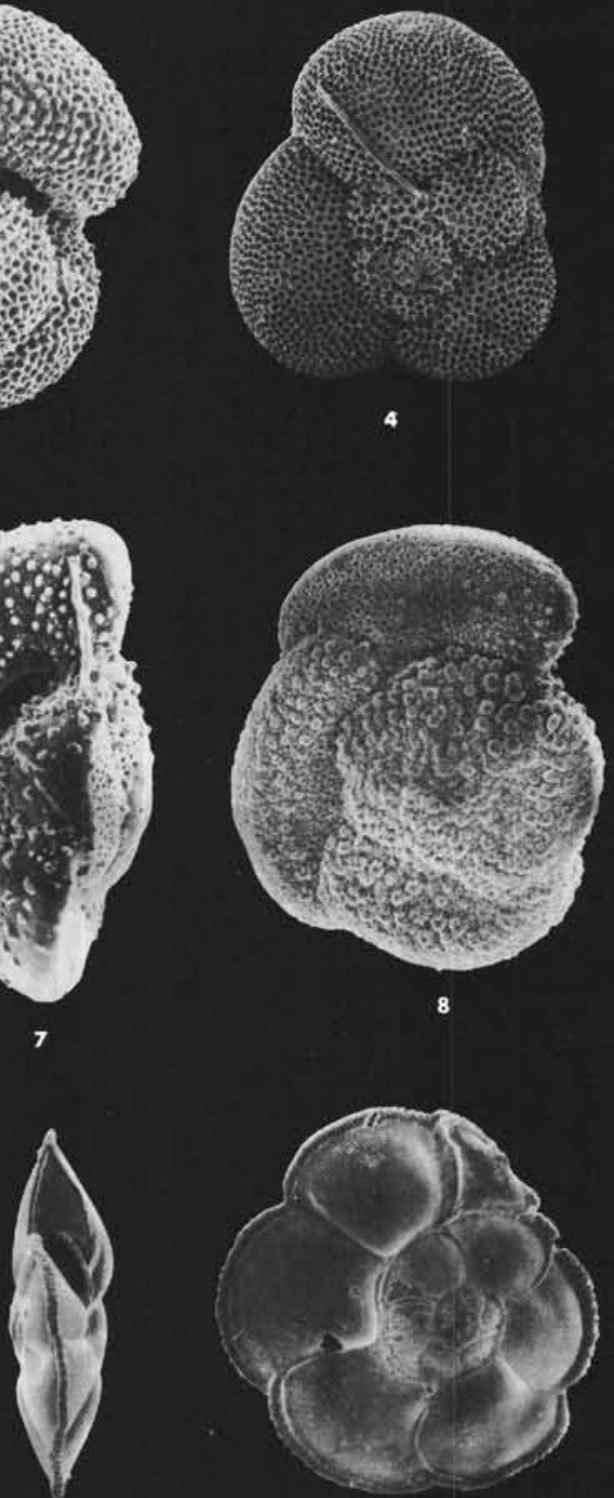

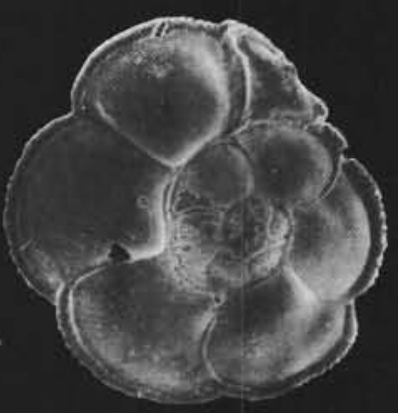

12

Plate 4. Neogene planktonic foraminifers. 1-5. Globoquadrina pseudofoliata, lower Pliocene, $(1,4)$ Sample 503B-22,CC, $(2,3,5)$ Sample 503B18 , CC, (1) ventral view $\times 93$, (2) ventral view $\times 96$, (3) side view $\times 107,(4)$ dorsal view $\times 69,(5)$ dorsal view $\times 86$. 6-8. Globorotalia crassaformis. (6) Sample 502A-29,CC, lower Pliocene, ventral view $\times 111,(7,8)$ Sample 502B-12,CC, upper Pliocene, (7) side view $\times 166$, (8) dorsal view $\times 111$. 9-12. Globorotalia exilis, Sample 502B-12,CC, upper Pliocene, (9) ventral view $\times 77,(10)$ ventral view $\times 73,(11)$ side view $\times 58,(12)$ dorsal view $\times 63$. 


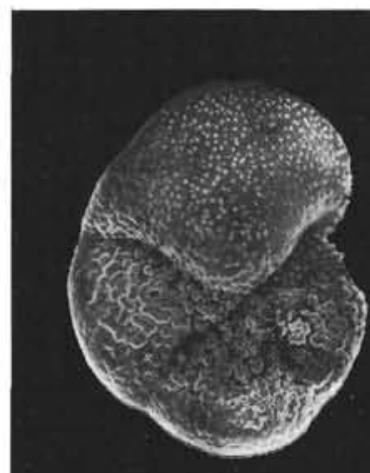

1

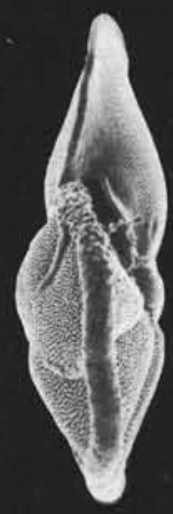

5

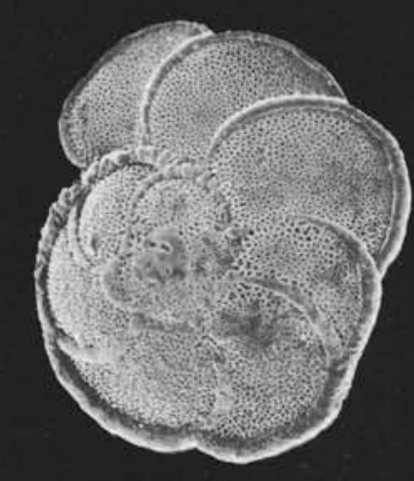

9
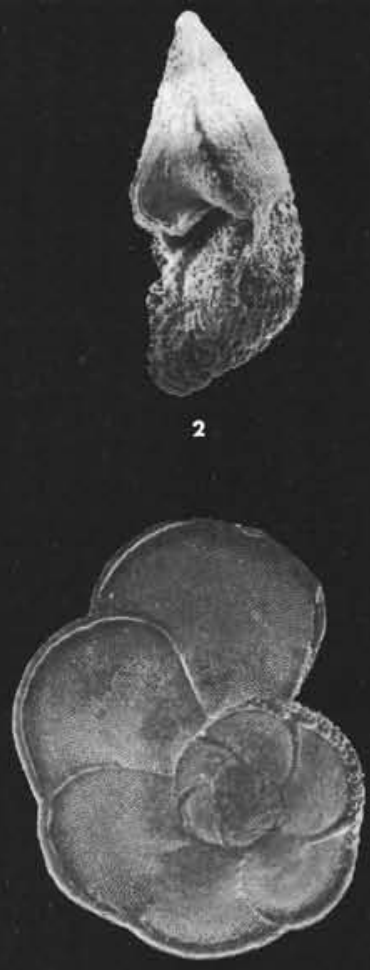

6

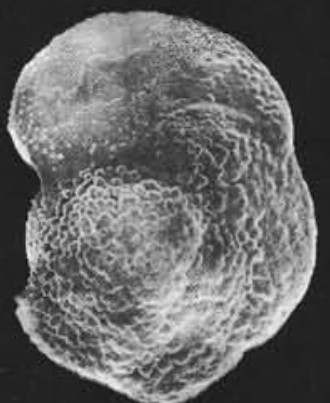

3

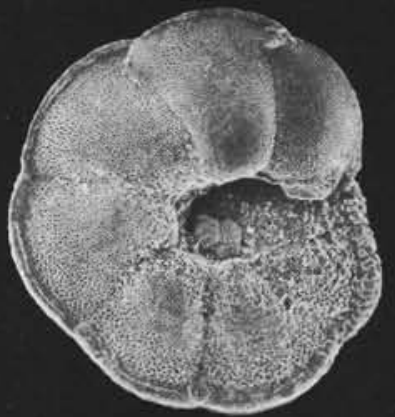

7

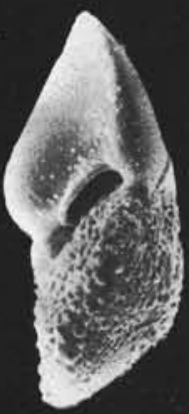

11
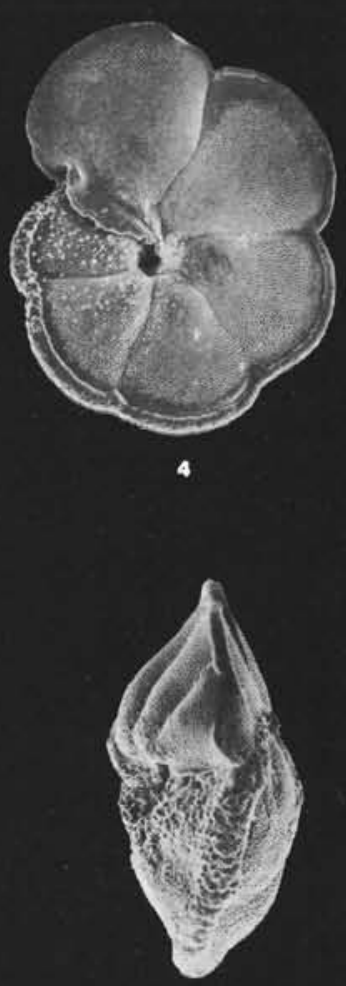

8

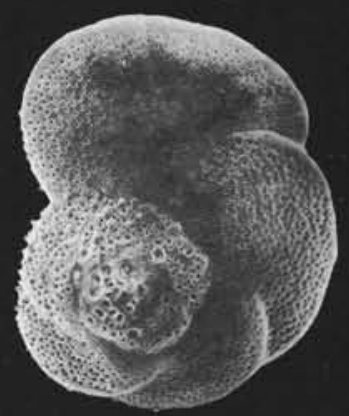

12

Plate 5. Neogene planktonic foraminifers. 1-3. Globorotalia hirsuta, Sample 502-18,CC, upper Pliocene, (1) ventral view $\times 72,(2)$ side view $\times 82$, (3) dorsal view $\times 66$. 4-6. Globorotalia limbata-Globorotalia exilis, Sample 503A-39,CC, upper Miocene, (4) ventral view $\times 66,(5)$ side view $\times 74,(6)$ dorsal view $\times 60$. 7-9. Globorotalia limbata-Globorotalia multicamerata, Sample 502A-45, CC, upper Miocene, (7) ventral view $\times 64$, (8) side view $\times 66$, (9) dorsal view $\times 79$. 10-12. Globorotalia margaritae, $(10,11)$ Sample 502-33,CC, lower Pliocene, $(12)$ Sample $502 \mathrm{~A}-38, C \mathrm{C}$, upper Miocene, $(10)$ ventral view $\times 110$, (11) side view $\times 110,(12)$ dorsal view $\times 110$. 


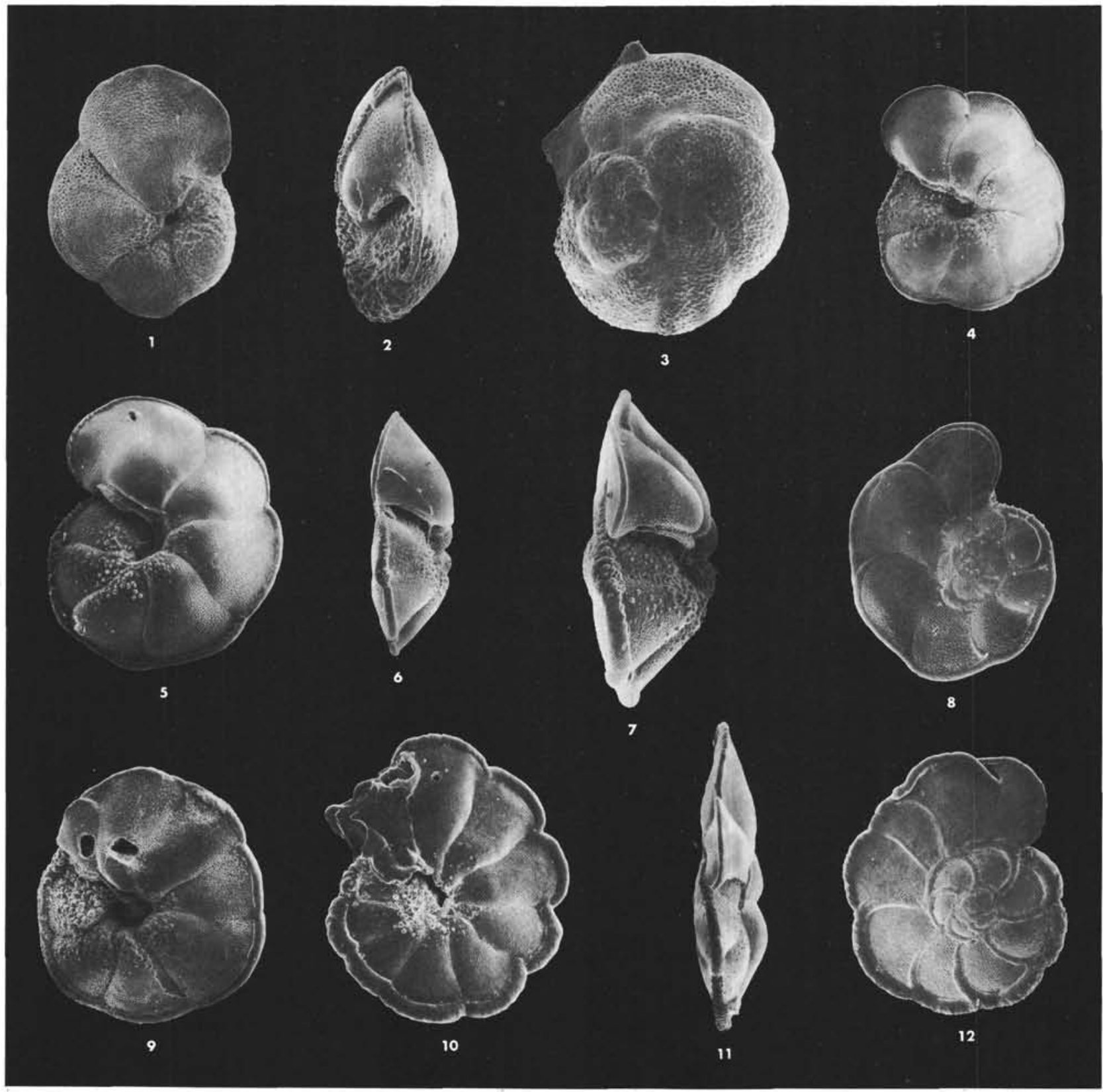

Plate 6. Neogene planktonic foraminifers. 1-3. Globorotalia sp. cf G. margaritae, (1) Sample 502A-38,CC, upper Miocene, ventral view $\times 66$, (2) Sample 502A-37,CC, lower Pliocene, side view $\times 93$, (3) Sample 502A-38,CC, upper Miocene, dorsal view $\times 99$. 4-8. Globorotalia miocenica, Sample 502B-12,CC, upper Pliocene, (4) ventral view $\times 55$, (5) ventral view $\times 77,(6)$ side view $\times 60$, (7) side view $\times 91$, (8) dorsal view $\times 71$. 9. Globorotalia multicamerata, Sample 502A-34,CC, lower Pliocene, ventral view $\times 71$. 10-12. Globorotalia pertenuis, (10) Sample 502A-21,CC, lower Pliocene, ventral view $\times 47,(11)$ Sample 502A-18,CC, upper Pliocene, side view $\times 47,(12)$ Sample 502A-21, CC, lower Pliocene, dorsal view $\times 47$. 


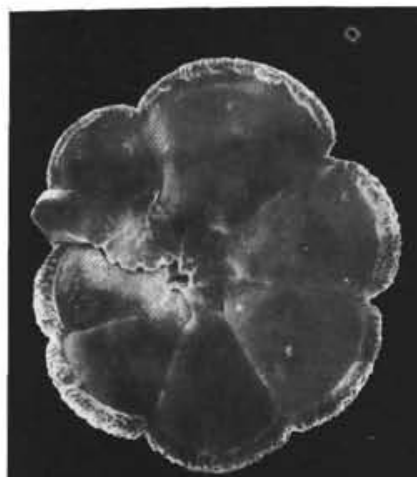

1

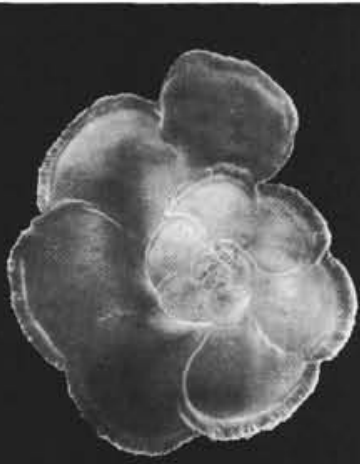

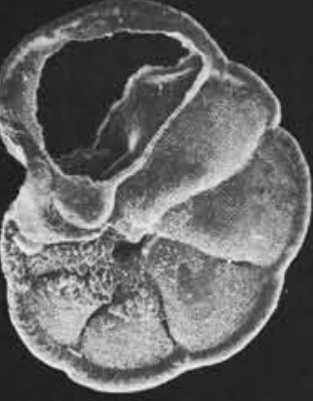

3

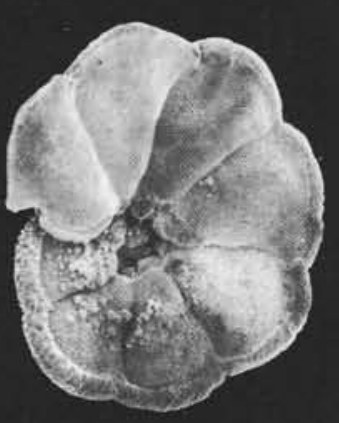

4

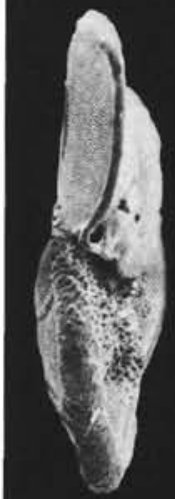

5

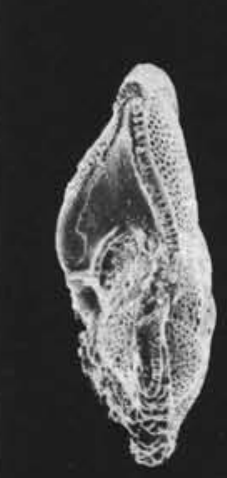

9
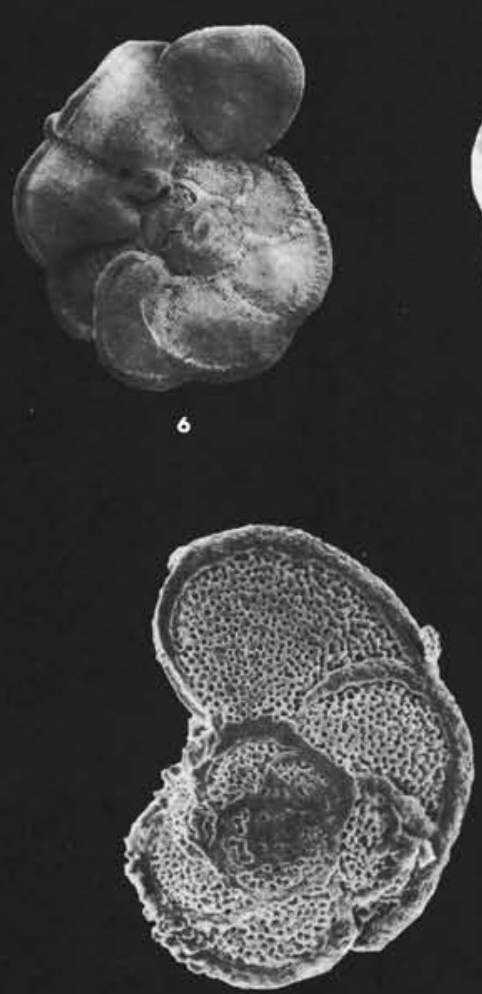

10

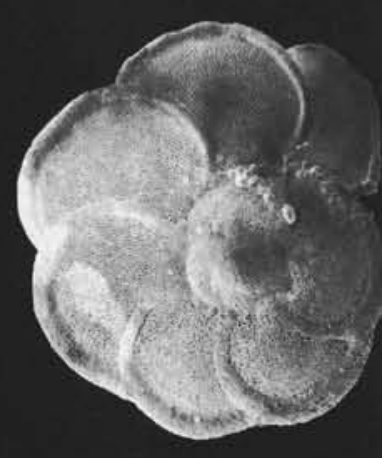

7

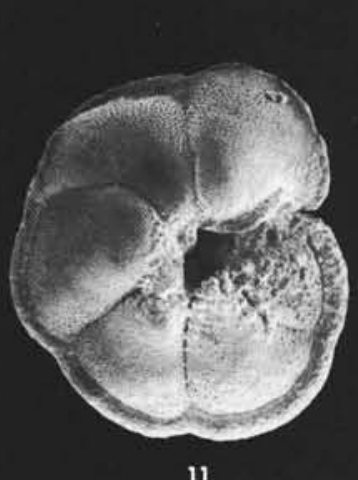

11

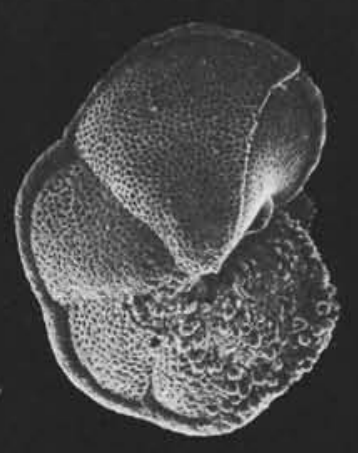

8

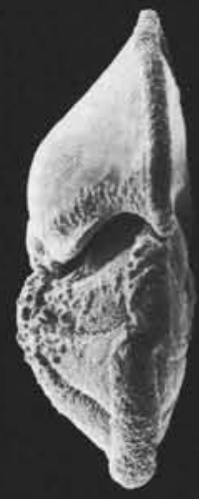

12

Plate 7. Neogene planktonic foraminifers. 1-7. Globorotalia pertenuis, $(1,2)$ Sample 502A-18,CC, upper Pliocene, (1) ventral view $\times 41$, (2) dorsal view $\times 47$, (3) Sample 503B-17-2, $106 \mathrm{~cm}$, lower Pliocene, ventral view $\times 40$, (4-7) Sample 503B-16,CC, lower Pliocene, (4) ventral view $\times 33$, (5) side view $\times 46$, (6) dorsal view $\times 31,(7)$ dorsal view $\times 42$. 8-10. Globorotalia pleisotumida, Sample 502C-30,CC, upper Miocene, (8) ventral view $\times 110$, (9) side view $\times 107,(10)$ dorsal view $\times 132$. 11-12. Globorotalia pseudomiocenica, Sample 502A-39,CC, upper Miocene, (11) ventral view $\times 77,(12)$ side view $\times 75$. 


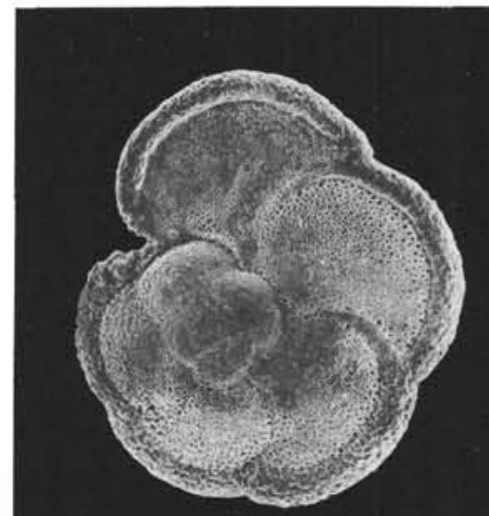

1$$
\text { , }
$$

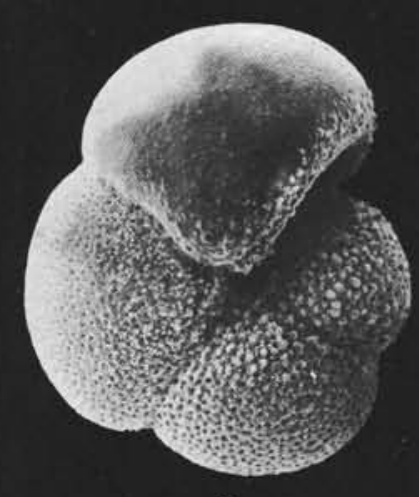

2

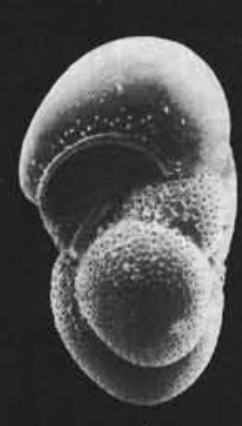

3

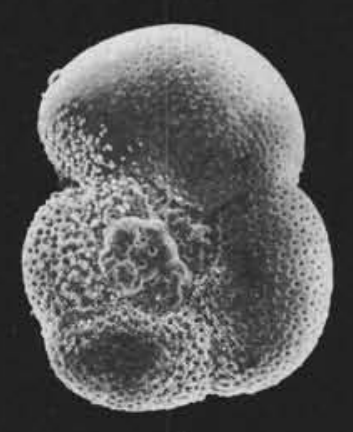

4

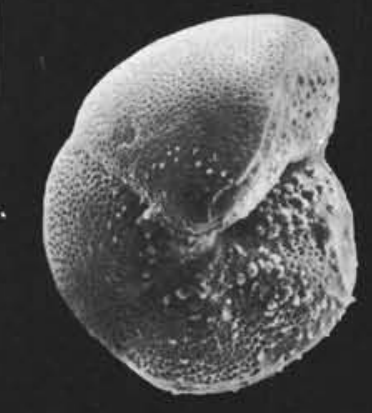

5

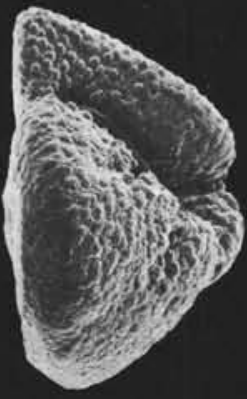

9

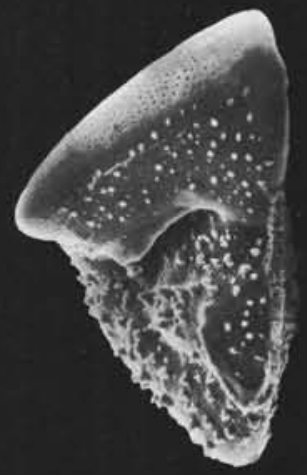

6

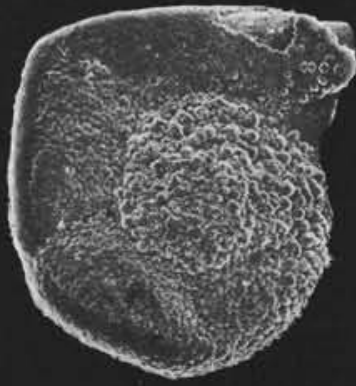

10

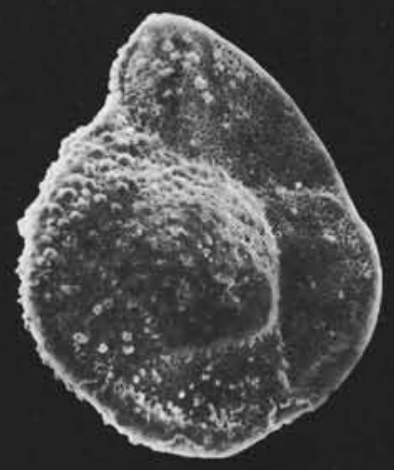

7

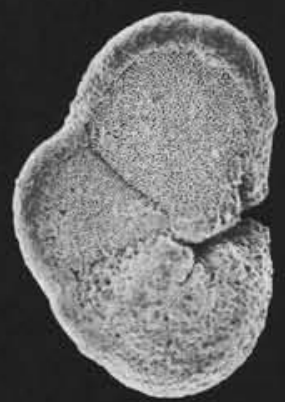

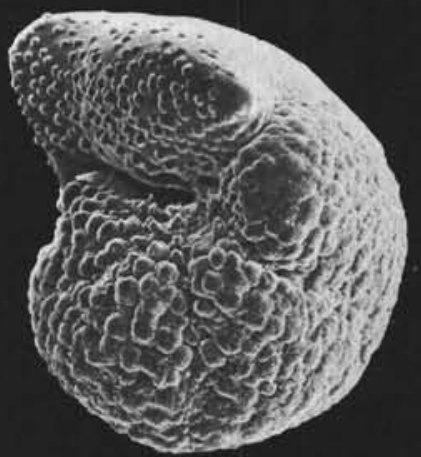

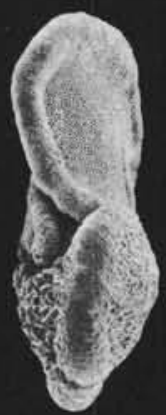

12

Plate 8. Neogene planktonic foraminifers. 1. Globorotalia pseudomiocenica, Sample 502A-39,CC, upper Miocene, dorsal view $\times 92$. $2-4$. Globorotalia puncticulata, Sample 502B-20,CC, lower Pliocene, (2) ventral view $\times 155$, (3) side view $\times 121,(4)$ dorsal view $\times 154$. 5-10. Globorotalia truncatulinoides, Pleistocene, (5-7) Sample 503B-8,CC; (8-10) Samples 502B-11-2, $108 \mathrm{~cm}$, $(5)$ ventral view $\times 154$, $(6)$ side view $\times 190$, (7) dorsal view $\times 157$, (8) ventral view $\times 132$, (9) side view $\times 93$, (10) dorsal view $\times 99$. 11-12. Globorotalia tumida, Sample 503B-19-2, 106 $\mathrm{cm}$., lower Pliocene, (11) ventral view $\times 48$, (12) side view $\times 46$. 


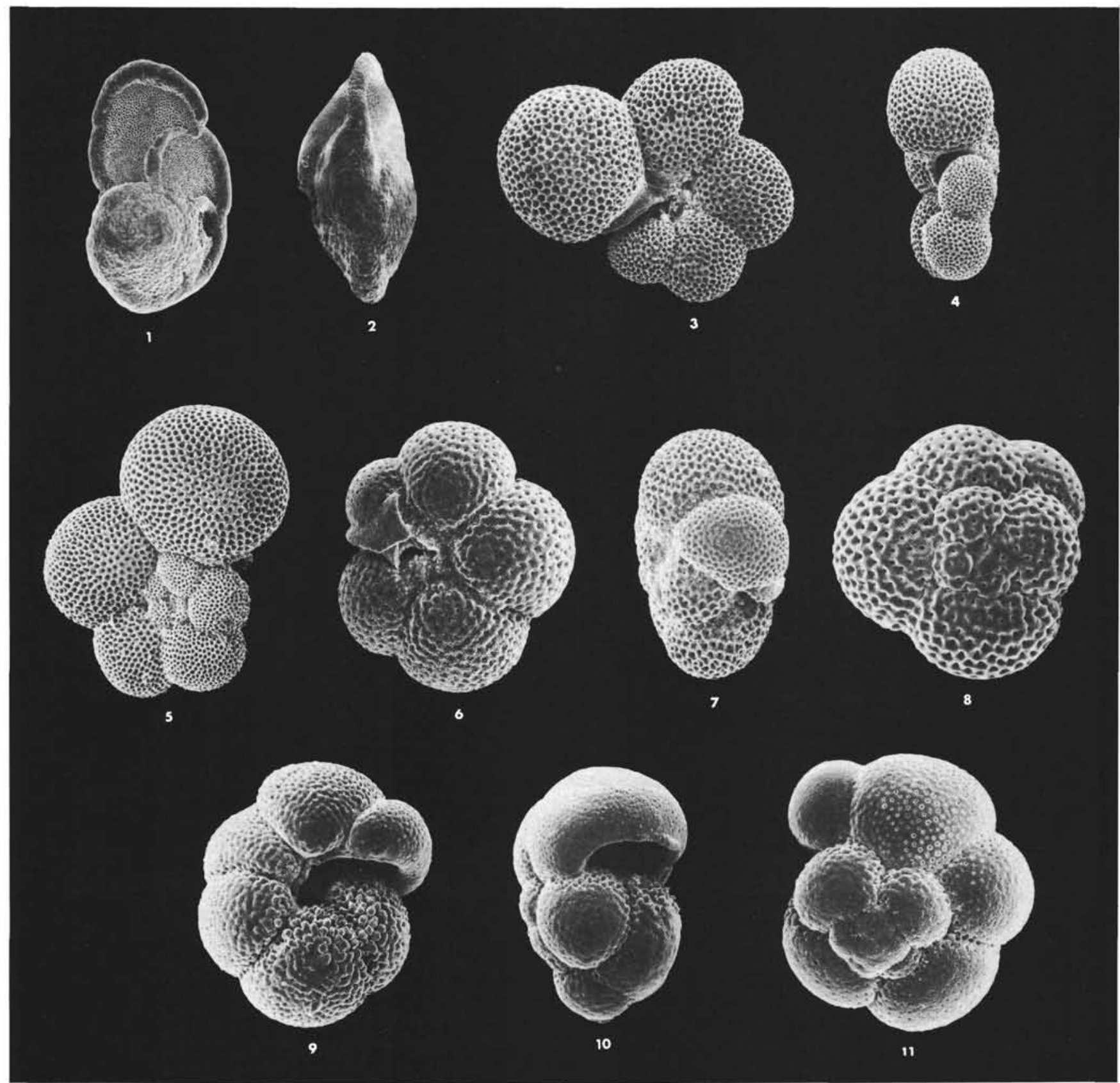

Plate 9. Neogene planktonic foraminifers. 1, 2. Globorotalia tumida, lower Pliocene, (1) Sample 503B-19-2, 106 cm, ventral view $\times 54$, (2) Sample 502A-37,CC, side view $\times 88$. 3-5. Globorotaloides hexagonus, Sample 503A-39-1, $106 \mathrm{~cm}$., upper Miocene, (3) ventral view $\times 132$, (4) side view $\times 111$, (5) dorsal view $\times 110$, 6-8. Neogloboquadrina acostaensis, Sample 502A-26,CC, lower Pliocene, (6) ventral view $\times 132$, (7) side view $\times 134$, (8) dorsal view $\times 175$. 9-11. Neogloboquadrina humerosa, Sample 503A-37-1, $106 \mathrm{~cm}$., upper Miocene, (9) ventral view $\times 110$, (10) side view $\times 93,(11)$ dorsal view $\times 135$. 


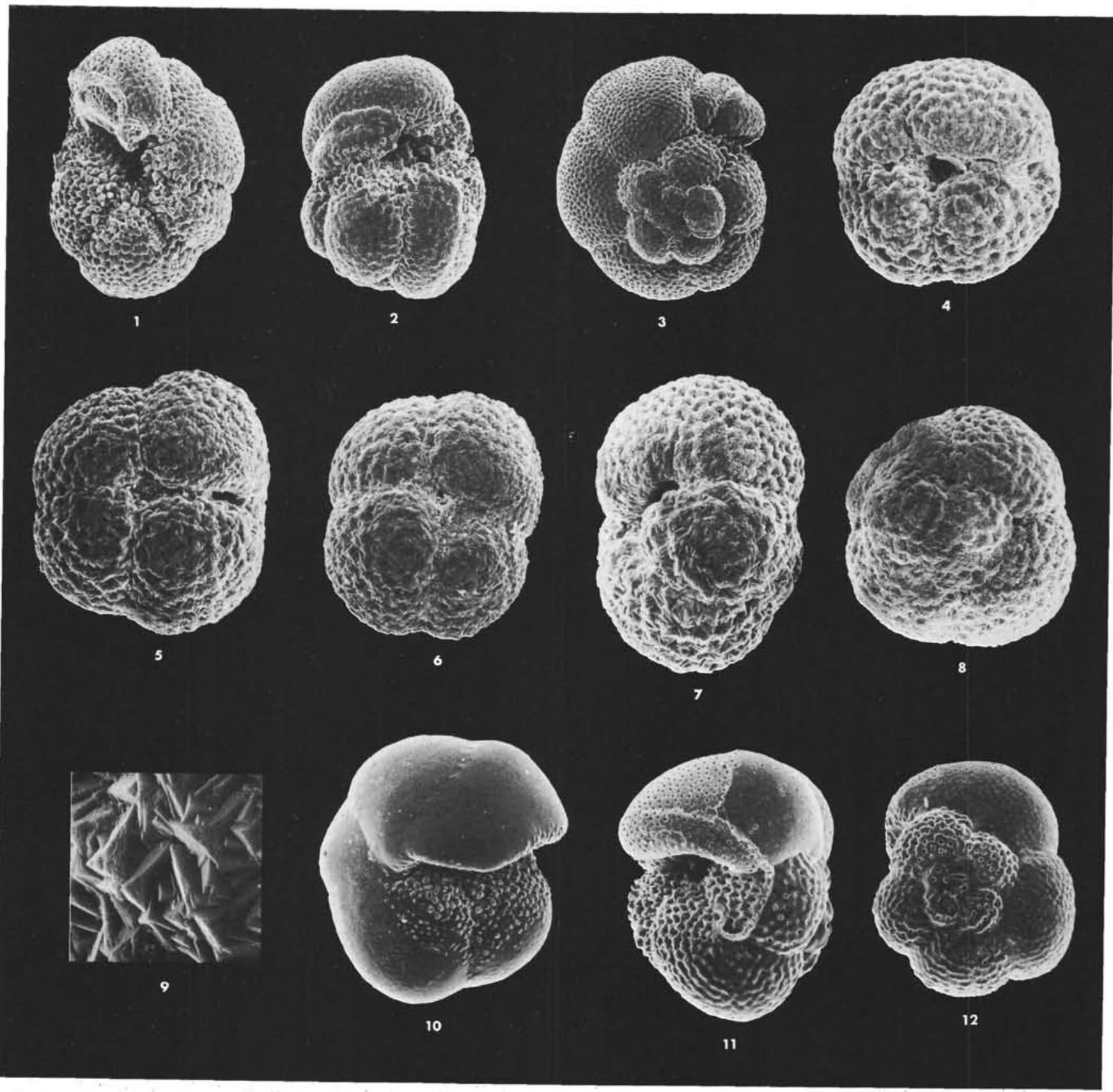

Plate 10. Neogene planktonic foraminifers. 1-3. Neogloboquadrina dutertrei, Sample 503A-9-1, $106 \mathrm{~cm}$, upper Pliocene, (1) ventral view $\times 96$, (2) side view $\times 96$, (3) dorsal view $\times 86$. 4-8. Neogloboquadrina pachyderma (sinistral phenotype), $(4,5,7,8)$ Sample 502A-39,CC, upper Miocene, (6) Sample 502A-37,CC, lower Pliocene, (4) ventral view $\times 200,(5)$ ventral view $\times 214$, (6) ventral view $\times 188$, (7) side view $\times 211,(8)$ dorsal view $\times 198$. 9. Ultrastructure of Fig. $6, \times 1125$. $10-12$. Pulleniatina primalis, Sample 503B-25-2, 102, lower Pliocene, $(10)$ ventral
view $\times 126,(11)$ side view $\times 154,(12)$, dorsal view $\times 188$. 


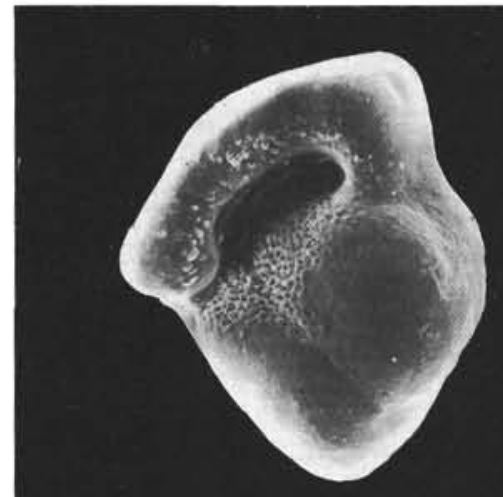

1

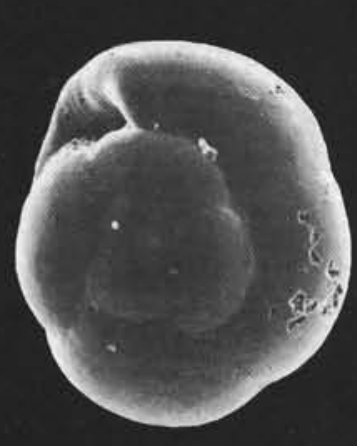

4

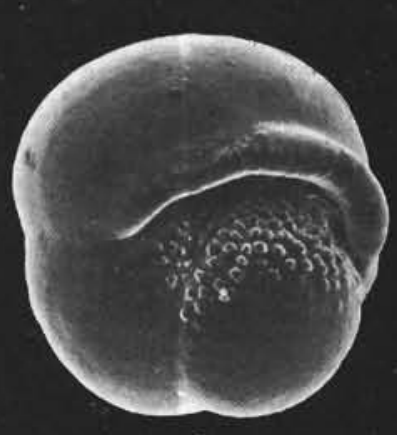

2

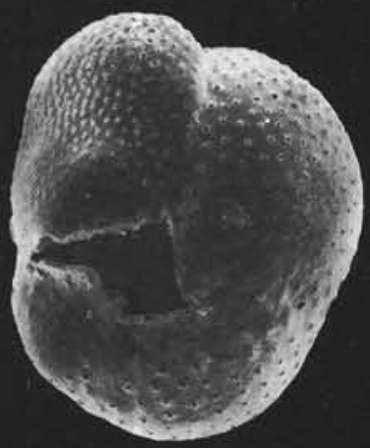

5

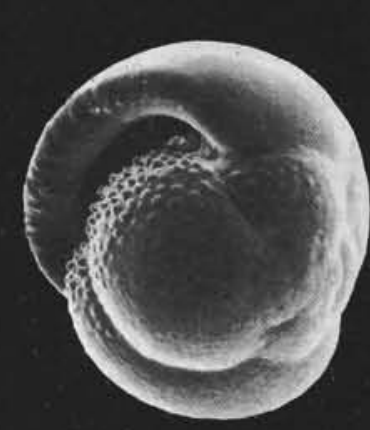

3

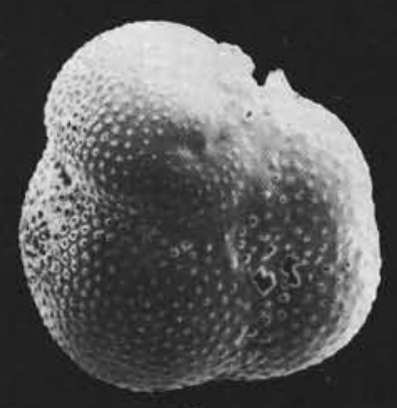

6

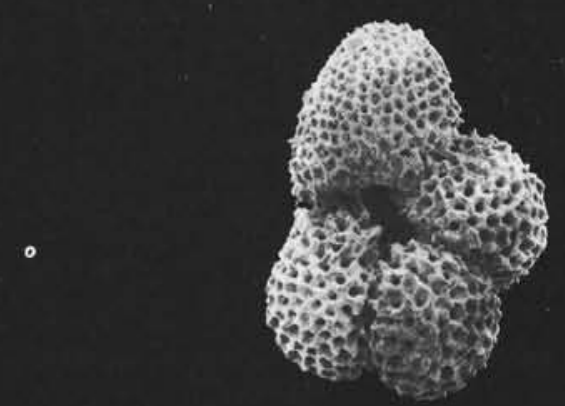

7

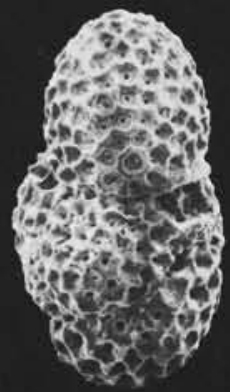

8

Plate 11. Neogene planktonic foraminifers, 1. Pulleniatina spectabilis, Sample 503B-23,CC, lower Pliocene, side view $\times 92$. 2-4. Pulleniatina obliquiloculata, Sample 502B-11-2, $108 \mathrm{~cm}$, upper Pliocene, (2) ventral view $\times 121$, (3) side view $\times 100$, (4) dorsal view $\times 86$. 5, 6 . Sphaeroidinella dehiscens (forma immatura), lower Pliocene, (5) Sample 503A-31,CC, ventral view $\times 82$, (6) Sample 502A-33,CC, dorsal view $\times 60$. 7, 8. Sphaerodinellopsis seminulina, Sample 502A-20-2, $52 \mathrm{~cm}$., lower Pliocene, (7) ventral viẹw $\times 51$, (8) side view $\times 99$. 